University of San Diego

Digital USD

Spring 5-31-2020

\title{
Effects of Standardized Self-Care Behavior Education on Self- Efficacy Outcomes in Type II Diabetes Mellitus
}

Nishita Patolia BSN, RN, DNP Student

University of San Diego, npatolia@sandiego.edu

Follow this and additional works at: https://digital.sandiego.edu/dnp

Part of the Family Practice Nursing Commons

\section{Digital USD Citation}

Patolia, Nishita BSN, RN, DNP Student, "Effects of Standardized Self-Care Behavior Education on SelfEfficacy Outcomes in Type II Diabetes Mellitus" (2020). Doctor of Nursing Practice Final Manuscripts. 124.

https://digital.sandiego.edu/dnp/124

This Doctor of Nursing Practice Final Manuscript is brought to you for free and open access by the Theses and Dissertations at Digital USD. It has been accepted for inclusion in Doctor of Nursing Practice Final Manuscripts by an authorized administrator of Digital USD. For more information, please contact digital@sandiego.edu. 


\title{
UNIVERSITY OF SAN DIEGO
}

Hahn School of Nursing and Health Science

DOCTOR OF NURSING PRACTICE

\begin{abstract}
Effects of Standardized Self-Care Behavior Education on Self-Efficacy
Outcomes in Type II Diabetes Mellitus
\end{abstract}

by

Nishita Patolia BSN, RN, DNP Student

A Doctor of Nursing Practice Portfolio presented to the

\section{FACULTY OF THE HAHN SCHOOL OF NURSING AND HEALTH SCIENCE UNIVERSITY OF SAN DIEGO}

\author{
In partial fulfillment of the \\ requirements for the degree \\ DOCTOR OF NURSING PRACTICE
}

May / 2020

Kevin J Maxwell PHD, DNP, FNP-BC, Faculty Advisor Dr. John Harper III MD, Clinical Mentor 


\section{Table of Contents}

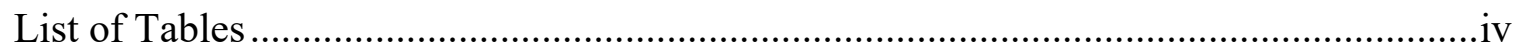

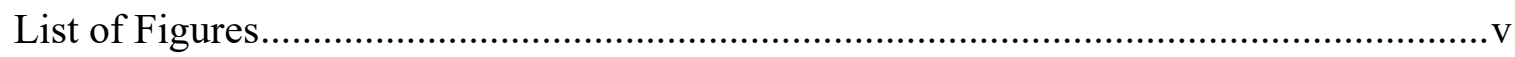

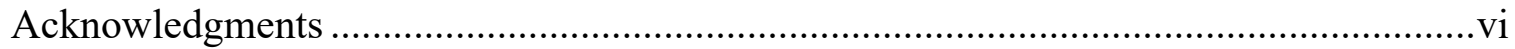

Opening Statement Purpose in Pursuing the DNP ....................................................... 1

Documentation of Mastery of DNP Program Outcomes ............................................2

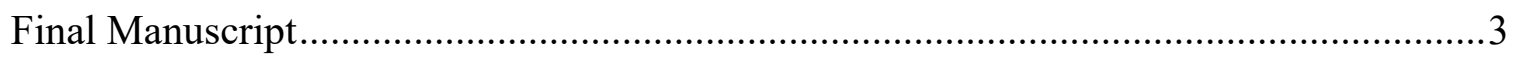

Abstract............................................................................................... 4

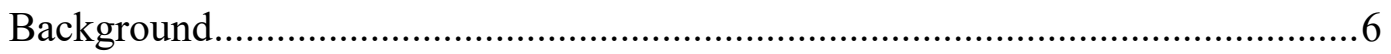

PICOT Question .................................................................................... 7

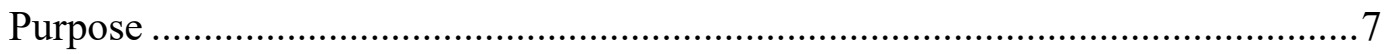

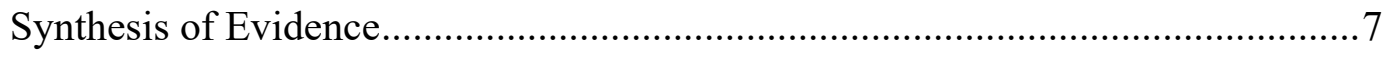

Evidence Based Practice Model ..................................................................... 8

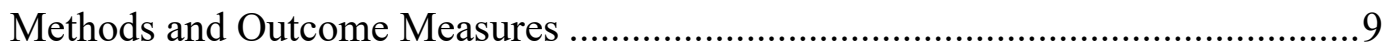

Project Development and Implementation Timelines ..................................... 10

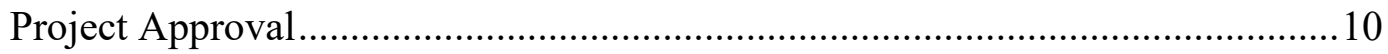

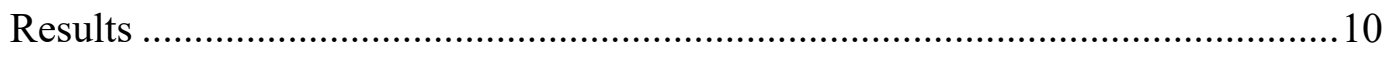

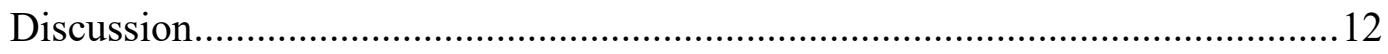

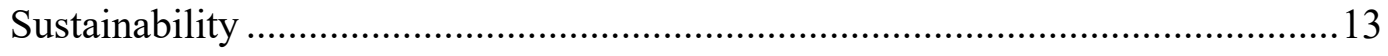

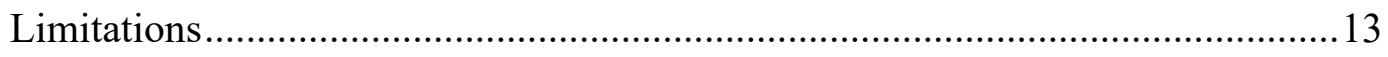

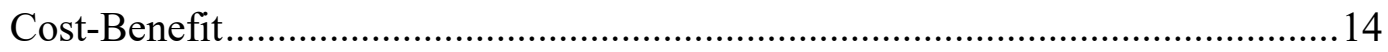

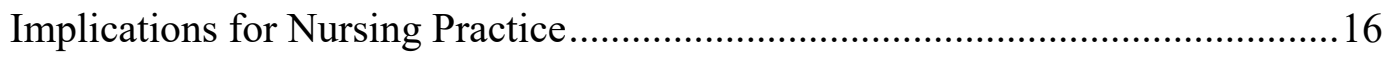

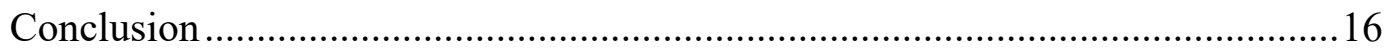




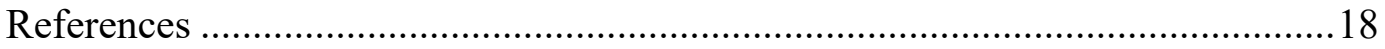

Project Development and Implementation Timeline............................................20

Concluding Essay: Reflections on Growth in Advanced Practice Nursing Role ..............21

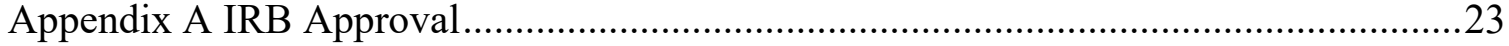

Appendix B Letter of Support from Clinical Site ………………..................................25

Appendix C Poster Abstract with Letter of Acceptance to Conference ..............................26

California Association for Nurse Practitioners Letter of Acceptance ...................27

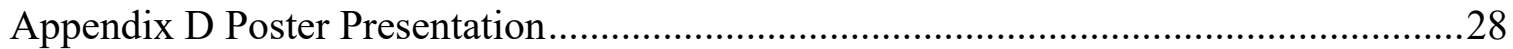

Appendix E PowerPoint Stakeholder Presentation …………......................................29

Appendix F DNP Program Outcomes Exemplars .............................................................39

Appendix G Other Supporting Documents …………...................................................53

Appendix H Certificates or Documentation of any Additional Certifications ...................54 


\section{List of Tables}

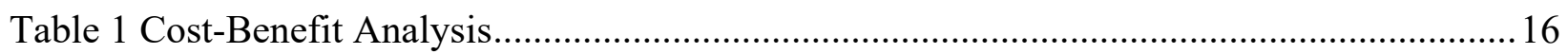




\section{List of Figures}

Figure 1 Stanford Patient Self Efficacy Results .............................................................. 12

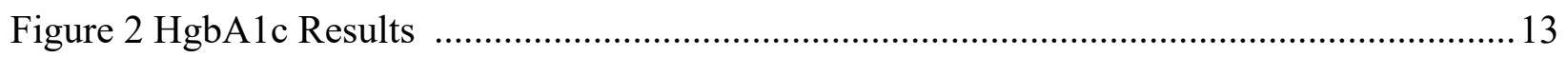




\section{Acknowledgments}

To my faculty advisor, Kevin J Maxwell PHD, DNP, FNP-BC, I could not have chosen a better individual to guide me through this program. Thank you for your wisdom, patience, continued guidance, and support through my doctoral journey. To my clinical mentor, Dr. John Harper, MD, thank you for your sincere dedication and for allowing me to do this project at your clinic. I owe this project's success to you and the staff at Dr. John R. Harper, III MD a Professional Corporation who went above and beyond to help me at each and every step.

To Dr. Donna Agan, EdD, thank you for your expertise in data analysis and support in finalizing this project.

To my classmates who have turned into family, Nienke Sahelijo, Sharon Anthony, Jenna Juenger, Spana Patel, Gizzele Valencia, Valerie Gates, Rachel Gerard, Kristian Jamerson, and Andrea Bell, thank you for keeping me motivated and inspiring me throughout this journey. To my parents, Rasik and Manisha Patolia, brother, Neal Patolia, and the rest of my family, thank you for your endless support, patience, and love for me during my doctoral program. I hope I made you all proud. 


\section{Opening Statement}

\section{Purpose in Pursuing the DNP}

It has been an honor and privilege serving as a Registered Nurse and helping my patients and families during their most vulnerable times. The Doctor of Nursing Practice program at University of San Diego has helped me grow academically as a nurse and improve patient safety by advancing nursing quality. Participation in this program has given me the tools I needed to grow intellectually in the healthcare field by allowing me to learn autonomously and develop a strong support system of peers and faculty.

The hands-on experience that I have gained from clinical rotations and the guidance of the faculty has given me the determination to pioneer and enhance new healthcare standards to help people of all ages and social backgrounds. My long-term goal is to open a clinic that is accessible to individuals of all socioeconomic backgrounds and provide sustainable health care to those that need it the most.

As a nurse I have the duty to make a difference in and improve the lives of my patients and their families. Embracing this philosophy in my everyday practice has encouraged me to incorporate the mind, body, and soul into my clinical practice as a Registered Nurse. I plan to integrate evidenced-based practice into my nursing care, allowing me to treat my patients holistically and prevent future complications through the use of diagnosis and education. University of San Diego's focus on developing difference makers has been an ideal fit for my personality and has provided me a simulating environment to nurture my passion of becoming a Nurse Practitioner. 
Documentation of Mastery of DNP Program Outcomes 


\title{
Final Manuscript
}

Effects of Standardized Self-Care Behavior Education on Self-Efficacy

Outcomes in Type II Diabetes Mellitus

\author{
Nishita Patolia \\ Kevin J Maxwell \\ University of San Diego
}




\begin{abstract}
An evidence-based practice (EBP) project was implemented in a primary care setting to decrease Hemoglobin A1c (HgbA1c) levels and increase self-efficacy in Type II Diabetes Mellitus (T2DM) diagnosed individuals. According to the Centers for Disease Control (CDC, 30.3 million adults have diabetes in the United States, and one in four do not know they have it (CDC, 2017). It is a disease that can be managed and reversed with standardized selfmanagement education. Self-management interventions can improve diabetes knowledge and encourage patient participation in caring for their health (Flode, Iversen, Aarflot, \& Haltbakk, 2017).
\end{abstract}

The purpose of this evidence-based project was to improve type II diabetes mellitus (T2DM) self-management through nursing education, focusing on self-efficacy and medication adherence guided by the American Association of Diabetes Educators 7 Self-Care Behaviors (AADE7). The objectives were: (a) decrease HgbA1c levels by $0.5 \%$ or more and (b) increase self-efficacy by $15 \%$ with the use of the Stanford Patient Education Resource Center's SelfEfficacy for Diabetes questionnaire (SPSE).

Eleven participants were recruited through provider referrals, flyers, and cold calls. Inclusion criteria included a T2DM diagnosis and HgbA1c greater than or equal to 7\%. It was a requirement to obtain a HgbAlc level and fill out the SPSE prior to the intervention. Each participant received personalized nurse-led education, which included healthy eating, medication adherence, exercise, healthy coping and reducing risks.

A total of 10 participants completed the program, including obtaining HgbAlc levels three months postintervention. There was significant improvement in postintervention scores with the mean increasing from 6.16 to $7.8\left(\mathrm{M}_{\text {pre }}=6.16, \mathrm{M}_{\text {post }}=7.80\right.$ on $1-10$ scale; $t=3.697, p$ 
$<.01)$. HgbAlc levels decreased in seven of 10 participants $(8.84$ to $7.64, t=1.692, p>0.05)$, suggesting possible influence in long-term self-care in most but not all patients' preendocrinology referral. Due to a small sample size, there were not enough participants to show statistical significance. Expanding the project to more patients with longer follow-up could help determine if DSME has significant long-term effects on HgbAlc and self-care behaviors. 


\section{Effects of Standardized Self-Care Behavior Education on Self-Efficacy \\ Outcomes in Type II Diabetes Mellitus}

Diabetes was the seventh leading cause of death in the United States in 2015, and the number continues to rise in how many individuals are diagnosed with type II diabetes mellitus (T2DM) every day (Centers for Disease Control and Prevention [CDC], 2017). The development of T2DM can go unnoticed for many years, usually with few or no symptoms. However, uncontrolled diabetes is the number one cause of kidney failure, lower-limb amputations, and adult blindness (CDC, 2017). Many lifestyle factors affect the probability of developing T2DM, such as being overweight, physically inactive, age (over 45 years), having a family member with the disease, and having gestational diabetes during pregnancy (CDC, 2017).

Type II diabetes mellitus can be prevented or delayed by changing many risk factors, such as by exercising or eating healthy. It is an expensive disease to manage, with an average cost of $\$ 13,247$ in medical expenditures per year (Yang et al., 2018). In 2017, the estimated cost of T2DM in the United States was $\$ 327$ billion for medical expenses and lost productivity (Yang et al., 2018). T2DM can easily be prevented with standardized education, lifestyle modifications, and frequent monitoring of blood glucose levels.

\section{Background}

The evidenced-based practice (EBP) project took place in a primary care setting, which consists of three providers who care for individuals in the surrounding area. The Doctor of Nursing Practice (DNP) student conducted a needs assessment by evaluating patient diagnoses and discussion with the clinic providers. According to the lead provider, most T2DM patients struggled with changing lifestyle habits, such as diet, exercise, and medication adherence. Risk factors and importance of making such changes are reinforced at every appointment, however 
there was a need to provide diabetes self-management education (DSME) to include more tailored information to the needs of each patient.

\section{PICOT Question}

In adults diagnosed with T2DM and a HgbA1c greater than or equal to 7\%, does the use of nurse-led diabetes self-management education compared to none decrease HgbA1c by $0.5 \%$ or more and increase self-efficacy by $15 \%$ with the use of the Stanford Patient Education Resource Center Self-Efficacy for Diabetes questionnaire?

\section{Purpose}

The purpose of this evidence-based practice project was to improve T2DM selfmanagement through nursing education, focusing on self-efficacy guided by the American Association of Diabetes Educators 7 Self Care Behaviors (AADE7). The objectives were: (a) decrease HgbA1c levels by $0.5 \%$ or more and (b) increase self-efficacy by $15 \%$ with the use of the SPSE questionnaire.

\section{Synthesis of Evidence}

A literature review was performed using the following search engines: PubMed, Cochrane, CINAHL, and Google Scholar. The search was limited to diabetes and selfmanagement research journals. Keywords used in the search were: Type II diabetes mellitus, Self-Management, HgbA1c, AADE7, self-care, diabetes knowledge scale, DSME, and poor glycemic control. The search yielded 364 related articles. A total of five articles were chosen to validate the EBP project interventions after further evaluation, which addressed diabetes education and management in the primary care setting. These articles were published in English in 1999 or later. 
A study conducted by Fokkens et al. (2011) demonstrated that standardized care leads to HgbAlc improvement and can lower blood pressure and cholesterol. The participants were followed for 1 year postintervention: research showed that overall patient wellness did not decline over time in contrast to the comparison group.

Evidence from another self-management education intervention showed that increased contact time can equally increase the positive effects of education, even though the benefits may decline 1-3 months after the intervention ceases (Norris et al., 2002). A long-term follow-up is necessary to support glycemic control and the benefits of the self-management education (Norris et al., 2002). A meta-analysis and meta-regression study conducted by Brown \& Hannis (1999) supports the efficacy of self-management education, displaying an improvement in knowledge, dietary compliance, skill performance, metabolic control, psychological outcomes, and weight loss. A nurse-led consultation-based intervention increased patient motivation by asking patients to write down and form action plans to improve self-efficacy (Farmer et al., 2012). An average HgbA1c change of $0.76 \%$ was seen during immediate follow-up, but a 23.6 -hour duration of contact time between the educator and patient is necessary for every $1 \%$ decrease in HgbA $1 \mathrm{c}$ (Norris, 2011). Patients with improved self-efficacy following education intervention were seen to have fewer hospitalization and emergency department visits as compared to a control group (Wu et al., 2011).

\section{Evidence Based Practice Model}

The Johns Hopkins nursing EBP model was used to successfully integrate this project into the clinic. It uses a problem-solving approach to clinical decision-making with a quick threestep process called "PET" (Dang \& Dearholt, 2017)The process includes inquiring about a practice problem, ranking evidence through a literature review and creating recommendations to 
be applied in the clinical practice setting (Dang \& Dearholt, 2017). The main goal of this model is to incorporate EBP efficiently and quickly into patient care (Dang \& Dearholt, 2017). The Johns Hopkins nursing evidence-based practice model fits the needs of the project by providing a detailed step-by-step breakdown of the three phases to smooth the transition by ranking each piece of evidence as either low, good, or high-quality evidence.

\section{Methods and Outcome Measures}

The EBP project's design was a study of 11 individuals diagnosed with T2DM in a primary care setting. Participants were informed of this project through word-of-mouth, flyers, and referrals from the providers at the clinic. Inclusion criteria stated that each participant must have a T2DM diagnosis and a HgbA1c greater or equal to 7\%. The sample consisted of individuals who were interested and willing to make a change in their lifestyle habits to better manage their diabetes outside of the clinic setting.

At the initial visit, each participant received the SPSE questionnaire to fill out before the appointment and again after the education had been provided by the DNP student. Participants were also required to provide an up to date $\mathrm{HgbA1c}$ level prior to the initial visit and 3 months following the education intervention. The intervention consisted of the participant receiving diabetes management education, which included healthy eating, medication adherence, exercise, healthy coping and reducing risks. Handouts from the AADE7 were provided in conjunction to the education, along with an example of diabetic friendly snacks from the American Diabetes Association. Participants were asked to set tangible goals guided by the AADE7 handouts and agree to adhere to changes in their lifestyle habits. Adjustments were made according to each participant's dietary restrictions and physical ability. Support was given through telephone follow-ups one month after the initial education had been provided to answer any questions or 
concerns the patient had. The average prequestionnaire results were $61.6 \%$ with an overall improvement of $14.8 \%$ by the end of the education intervention. There was a $1.1 \%$ average decrease in HgbA1c 3 months postintervention.

\section{Project Development and Implementation Timelines}

Many steps were taken to ensure the success of this EBP project implementation. The project's design was a quasi-experimental study of 11 participants in a primary care setting. The steps were: propose the project to Dr. Harper's clinic, obtain a letter of support from the clinical mentor, IRB submission and approval, recruit patients from the clinic, implementation, analyze data pre and post intervention, and discuss results during the stakeholder presentation. Refer to the appendix for a detailed timeline.

\section{Project Approval}

This project was implemented at a private primary care clinic in Ramona, California, which does not require Institutional Review Board (IRB) approval. The lead provider wrote a letter showing approval for this project to be implemented in the clinic. The IRB approval was, however, needed from the University of San Diego. Once the criteria to prove that the project was not research-based, the implementation process began. IRB approval, which included two letters of support and research training completion certificates, was completed by November 2019.

\section{Results}

Eleven individuals originally participated in the EBP project. However, a total of 10 participants completed the program, which included obtaining HgbAlc levels 3 months postintervention. The pre-post results for 11 participants were included in the self-efficacy results, but not in the $\mathrm{HgbA1c}$ results. 
The results were determined by comparing and calculating pre and postintervention scores of the SPSE questionnaire and HgbA1c results. Pre-intervention SPSE scores suggested varying levels of self-efficacy. However, there was significant improvement in postintervention scores with the mean increasing from 6.16 to 7.8 , an average of $16.4 \%$ increase in scores as seen in Figure $1\left(\mathrm{M}_{\text {pre }}=6.16, \mathrm{M}_{\text {post }}=7.80\right.$ on $1-10$ scale; $\left.t=3.697, p<.01\right)$.

\section{Figure 1}

Stanford Patient Self-Efficacy Results

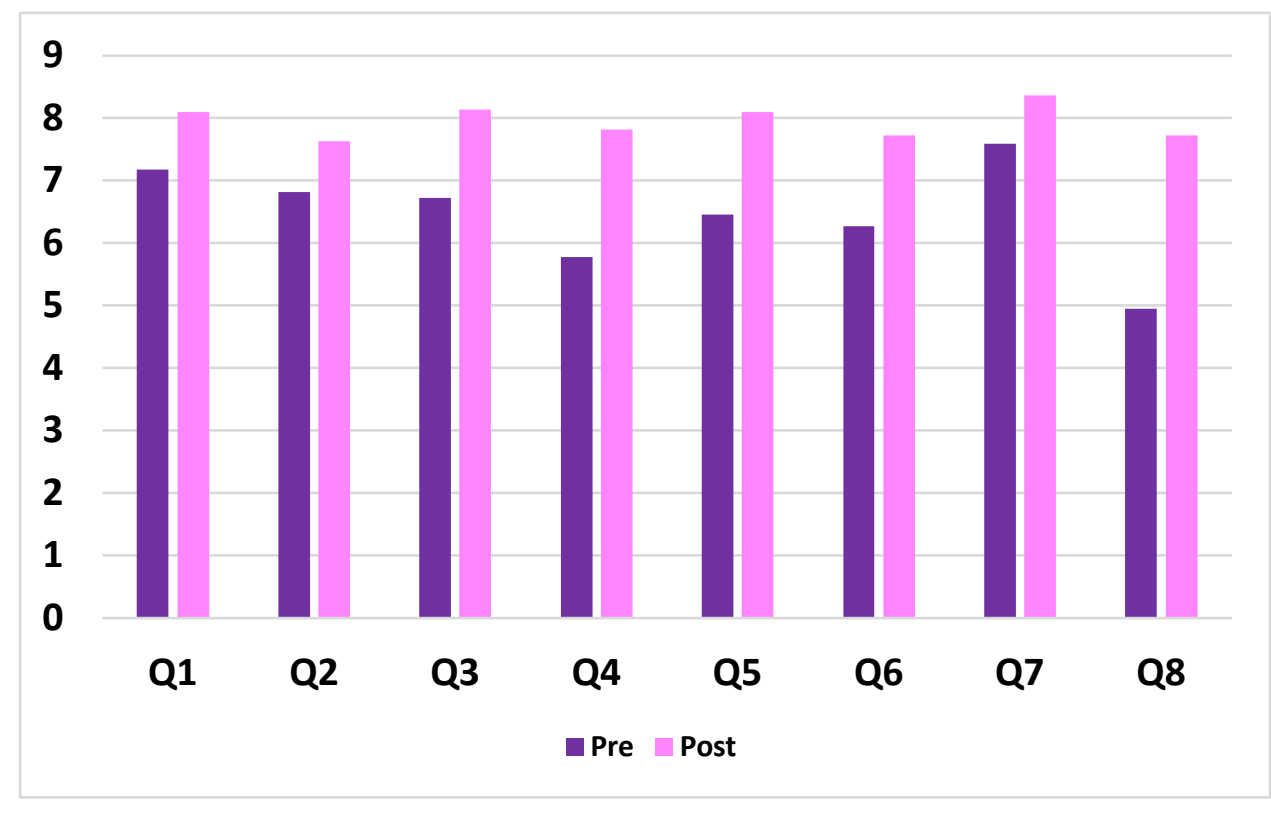

As seen in Figure 2, HgbA1c levels decreased in seven of 10 participants (8.84 to 7.64, $\mathrm{t}=1.692, \mathrm{p}>0.05$ ), suggesting possible influence in long-term selfcare in most but not all patients pre-endocrinology referral. Due to a small sample size, there were not enough participants to show statistical significance in HgbA1c levels. Three of the ten final participants had an increase in their HgbA1c ranging from $0.2-0.7 \%$. These individuals had a wide range of SPSE scores from 5-20\%. Expanding the project to more patients with longer follow-up could help determine if DSME has significant long-term effects on HgbA1c and self-care behaviors. 


\section{Figure 2}

HgbAlc Results

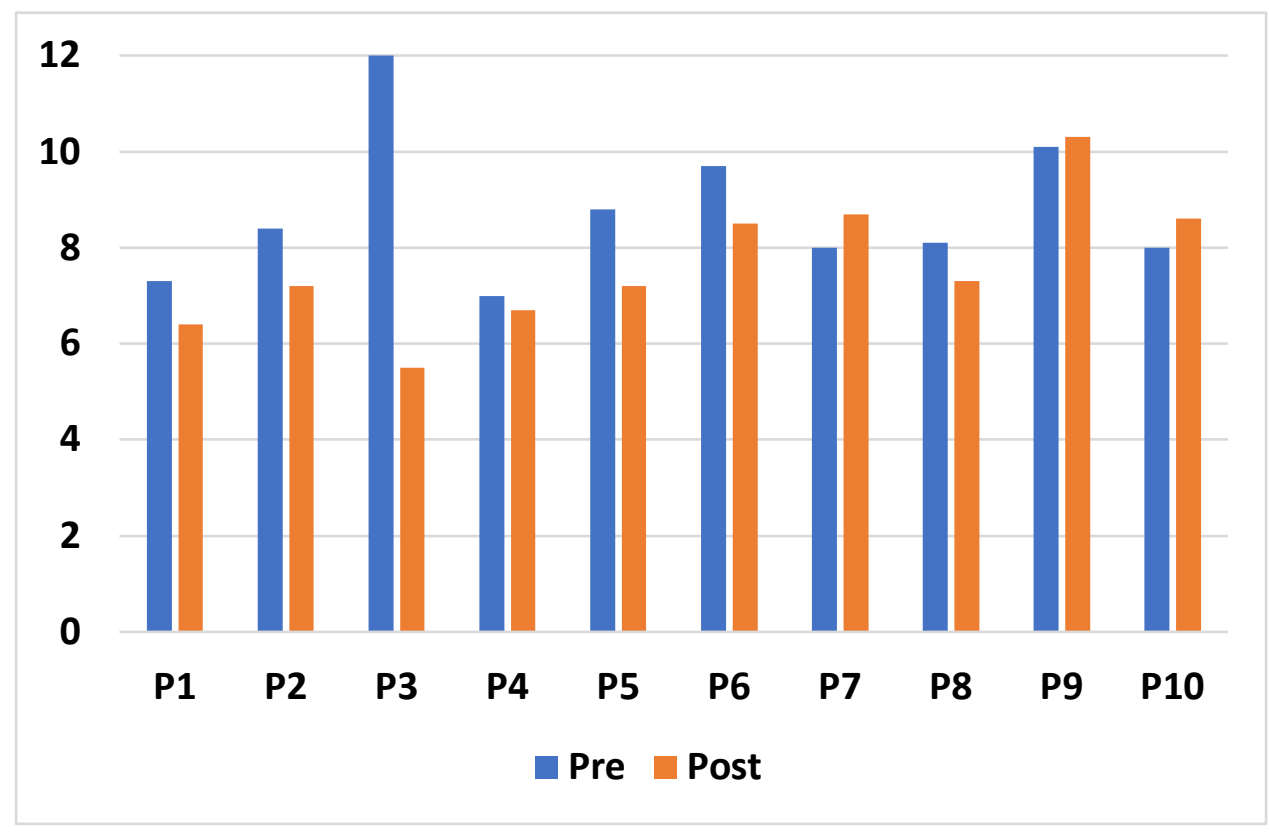

\section{Discussion}

The 11 participants' baseline PSME scores varied, but the mean score was 6.16. The postintervention score was 7.8, showing an increase of 1.64 points in self-efficacy. This indicates there was an improvement in self-efficacy in managing diabetes outside the clinical setting.

The DNP project utilized the AADE7 guidelines to discuss healthy eating, being active, monitoring blood glucose levels, taking medications, problem solving, healthy coping, and reducing risks with each participant. Although 11 participants initially participated in the project, 10 completed the project by providing HgbA1c levels 3 months post-DSME. The participant that was not able to give a HgbA1c level, was able to complete the SPSE pre-post intervention questionnaire. Out of the 10 final HgbA1c levels collected, seven showed improvement in levels and three did not. One participant decreased HgbA1c levels from $12 \%$ to $5.5 \%$ and had a $20.6 \%$ 
increase in the SPSE score. Another participant had an increase in HgbAlc levels from $8 \%$ to $8.7 \%$, and only had an increase in SPSE scores by 0.8 points.

Overall, the average SPSE scores improved, which quantified the positive effects of DSME on self-efficacy. Most patients found the information and guidance helpful in overall improving lifestyle for themselves and family members. There was positive feedback given for the resources and handouts utilized by the AADE7 and American Diabetes Association. DSME proved to be efficacious in increasing self-efficacy scores, but not improving HgbAlc levels in all participants. Reinforcement of DSME is necessary at every clinic appointment to support confidence in self-management and progressively decrease HgbA1c scores.

\section{Sustainability}

Although the EBP project was short-term, sustainability is key to maintaining long-term benefits for the participants. The first step for sustainability will be to have a second-year DNP student carry on the project and continue to analyze the benefits of self-management education. The DNP student can continue monitoring HgbA1C levels every 3 months and provide selfmanagement education to more T2DM patients in the clinic. Another step to ensure sustainability will be to nominate a clinic champion to support the application of this project at the clinic and continue the interventions. These two steps will provide greater potential for sustainability and establish a standard of care in the clinic.

\section{Limitations}

The DNP EBP project had several limitations, which included the limited time given in recruiting participants for the project to receive their follow-up HgbAlc on time. Three weeks were dedicated to enrolling participants and making appointments for the education intervention. 
Due to the limited time, there was a smaller sample size than expected. The DNP student was able to interest 10 participants for the EBP project.

The most challenging barrier was finding a middle ground with the patients and agreeing on lifestyle changes that were sustainable. A few individuals did not want to take part in any physical activity but were interested in making dietary changes. The city in which this EBP project took place also had limited affordable resources available for its communities, so participants were encouraged to safe hiking grounds and pathways near their residence. The intervention required providing multiple resources to facilitate the transition to the new lifestyle changes. These limitations were overcome by providing multiple resources to facilitate the transition to the new changes, such as YouTube, the Diabetes Educator website, MyFitnessPal, and Pinterest for diabetic-friendly food recipes.

Another limitation, which may have skewed HgbAlc levels, is that the project took place during the holiday season between November 2019 and January 2020, even though patients were encourage to moderate food intake during the holidays. During the literature review, it was speculated that most studies were only for short-term interventions and there was limited evidence to show long-term effected of self-management education. Further EBP projects should be conducted and examined to follow-up on long-term effects.

\section{Cost-Benefit}

The cost of implementing the EBP project was $\$ 93.18$. The only resources needed for each appointment were the pre and post questionnaires, patient handouts, and a blood lab draw for HgbAlc with the results before the day of the appointment. An additional blood lab draw was taken 3 months after the education had been provided to monitor for changes. Diabetes management education was reinforced during the telephone follow-up, where the patients were 
given an opportunity to express questions and concerns. The front-desk staff oversaw handing out and collecting prequestionnaires, making appointments, and ensuring each participant had an updated HgbA1c. Medical assistants collected blood samples, and the providers helped in recruiting participants. No additional costs were required for the clinic staff since the training occurred during office hours. Participation gift bags, which included healthy, diabetic-friendly snacks and drinks were given to each participant as an incentive and to encourage healthy eating.

The cost-benefit analysis showed that for every $\$ 93.18$ spent on DSME, there will be a benefit of annual savings of $\$ 4,910$. Therefore, every participant in the intervention, will see a 52.69-fold in cost savings. The EBP project yields a 5,169.4\% on return on investment. An estimate of the benefits for the potential increase in revenue is provided in Table 1.

Table 1

Cost-Benefit Analysis

\begin{tabular}{|c|c|c|}
\hline Resource & Cost & Rationale \\
\hline $\begin{array}{l}\text { Front Desk Staff } \\
\text { Training }\end{array}$ & $\$ 0.00$ & Completed during office hours \\
\hline $\begin{array}{l}\text { Pre- and Post-test } \\
\text { Print Outs }\end{array}$ & $\begin{array}{l}5 \notin / \text { page }(6 \\
\text { pages/patient) }\end{array}$ & $\begin{array}{l}\text { Education handouts and questionnaire } \\
\text { for the participants }\end{array}$ \\
\hline $\begin{array}{l}\text { Provider, medical } \\
\text { assistant, and } \\
\text { manager training }\end{array}$ & $\$ 0.00$ & Completed during office hours \\
\hline $\begin{array}{l}\text { HgbA1C Blood Lab } \\
\text { Draw }\end{array}$ & $\$ 0.00$ & Covered by medical insurance \\
\hline $\begin{array}{l}\text { Participation } \\
\text { giftbag }\end{array}$ & $\$ 90.18$ & Incentive for the project participants \\
\hline Benefit & Reimbursement (Savings) & Rationale \\
\hline Savings/patient/year & $\$ 4,910$ (Dall et al., 2016) & $\begin{array}{l}\text { Annual savings per patient with } \\
\text { controlled T2DM }\end{array}$ \\
\hline Intangible benefits & \multicolumn{2}{|c|}{$\begin{array}{l}\text { Improved self-efficacy of T2DM management } \\
\text { Improved quality of life }\end{array}$} \\
\hline
\end{tabular}




\begin{tabular}{cl}
\hline Cost Benefit & For 10 T2DM patients: \\
Analysis & CBA: $\$ 4910 / 93.18=52.69$ \\
& ROI: $(\$ 4910-\$ 93.18) \times 100=5,169.4 \%$ \\
& $\$ 93.18$ \\
\hline
\end{tabular}

\section{Implications for Nursing Practice}

Health care providers educating at the initial diabetes diagnosis can be beneficial to individuals in managing their health at home. Although medications can help decrease blood values, supplemental education regarding good lifestyle habits can prevent future complications. It is imperative that providers share resources that benefit diabetic individuals outside the clinic setting.

\section{Conclusion}

The author of the EBP project concluded that a detailed DSME can be beneficial in improving selfcare behavior management. Supplemental education for healthy lifestyle habits, such as diet and exercise, may decrease long-term risks and complications. It is the providers' role to include additional educational resources that benefit T2DM individuals outside the clinic setting. The purpose of this evidence-based practice project was to improve T2DM selfmanagement through nursing education, focusing on self-efficacy guided by the AADE7.

This project aimed to decrease HgbAlc levels by $>0.5$ and improve self-efficacy by $15 \%$ among 11 participants, however only 10 completed the study. Self-efficacy was measured pre and postintervention using the SSPE questionnaire. HgbA1c levels were measured pre-DSME and three months after. The results showed that there was significant improvement in in postintervention scores with the mean increasing from 6.16 to 7.8 , an average of $16.4 \%$ increase. HgbA1c levels decreased in seven of 10 participants. All participants provided positive feedback regarding resources and supplemental information provided during the DSME. A meta-analysis 
and meta-regression study conducted by Brown supports the efficacy of self-management education, displaying an improvement in knowledge, dietary compliance, skill performance, metabolic control, psychological outcomes, and weight loss (Brown \& Hannis, 1999). Providers' role includes providing additional resources that assist T2DM individuals decrease HgbA1c and improve self-care management behaviors outside the clinic. 


\section{References}

Brown, S. A., \& Hanis, C. L. (1999). Culturally competent diabetes education for Mexican Americans: The Starr County study. The Diabetes Educator, 25(2), 226-236. doi:10.1177/014572179902500208

Centers for Disease Control and Prevention. (2017). National diabetes statistics report. https://www.cdc.gov/diabetes/pdfs/data/statistics/national-diabetes-statistics-report.pdf

Dall, T. M., Yang, W., Halder, P., Franz, J., Byrne, E., Semilla, A. P., . . Stuart, B. (2016). Type 2 diabetes detection and management among insured adults. Population Health Metrics, 14, 43. doi:10.1186/s12963-016-0110-4

Dang, D., \& Dearholt, S. (2017). Johns Hopkins nursing evidence-based practice: Model and guidelines (3rd ed). Indianapolis, IN: Sigma Theta Tau International.

Farmer, A., Hardeman, W., Hughes, D., Prevost, A. T., Kim, Y., Craven, A., ... Kinmonth, A.-L. (2012). An explanatory randomised controlled trial of a nurse-led, consultation-based intervention to support patients with adherence to taking glucose lowering medication for type 2 diabetes. BMC Family Practice, 13(1), 30. doi:10.1186/1471-2296-13-30

Flode, M., Iversen, M. M., Aarflot, M., \& Haltbakk, J. (2017). Lasting impact of an implemented self-management programme for people with type 2 diabetes referred from primary care: a one-group, before-after design. Scandinavian Journal of Caring Science. 31(4), 789-795. doi:10.1111/scs. 12398

Fokkens, A. S., Wiegersma, P. A., Beltman, F. W., \& Reijneveld, S. A. (2011). Structured primary care for type 2 diabetes has positive effects on clinical outcomes. Journal of Evaluation in Clinical Practice, 17(6), 1083-1088. doi:10.1111/j.13652753.2010.01466.x 
Mayo Clinic. (2019). Type 2 diabetes - Symptoms and causes. Retrieved from https://www.mayoclinic.org/diseases-conditions/type-2-diabetes/symptoms-causes/syc20351193

Wu, S.-F., Lee, M.-C., Liang, S.-Y., Lu, Y.-Y., Wang, T.-J., \& Tung, H.-H. (2011). Effectiveness of a self-efficacy program for persons with diabetes: A randomized controlled trial. Nursing \& Health Sciences, 13(3), 335-343. doi:10.1111/j.14422018.2011.00625.x

Yang, W., Dall, T. M., Beronjia, K. Lin, J., Semilla, A. P., Chakrabarti, R. \& Hogan, P. F. Economic costs of diabetes in the U.S. in 2017. (2018). Diabetes Care, 41(5), 917. doi:10.2337/dci18-0007 


\section{Project Development and Implementation Timeline}

\begin{tabular}{|c|c|c|}
\hline Intervention/Activities & $\begin{array}{l}\text { Persons } \\
\text { Involved }\end{array}$ & $\begin{array}{l}\text { Estimated Time } \\
\text { Frame }\end{array}$ \\
\hline Proposal of project to private practice & $\begin{array}{l}\text { DNP Student } \\
\text { Dr. Harper }\end{array}$ & April 2019 \\
\hline Obtain letter of support from Director & $\begin{array}{l}\text { DNP Student } \\
\text { Dr. Harper }\end{array}$ & September 2019 \\
\hline USD IRB submission and acceptance & $\begin{array}{l}\text { DNP Student } \\
\text { Dr. Maxwell }\end{array}$ & September 2019 \\
\hline Recruitment of patients eligible for AAP education & $\begin{array}{l}\text { DNP Student } \\
\text { Dr. Harper }\end{array}$ & $\begin{array}{c}\text { October - November } \\
2019\end{array}$ \\
\hline Implementing AAP education & $\begin{array}{l}\text { DNP Student } \\
\text { Dr. Harper }\end{array}$ & November 2019 \\
\hline $\begin{array}{l}\text { Clean data and assert results from pre and post } \\
\text { ACT scores }\end{array}$ & $\begin{array}{l}\text { DNP Student } \\
\text { Dr. Maxwell }\end{array}$ & $\begin{array}{c}\text { December - February } \\
2020\end{array}$ \\
\hline $\begin{array}{l}\text { Dissemination of results at stakeholder } \\
\text { presentation }\end{array}$ & DNP Student & March 2020 \\
\hline Dissemination of results at CANP conference & DNP Student & March 2020 \\
\hline Graduate & DNP Student & May 2020 \\
\hline $\begin{array}{l}\text { Submission and acceptance of manuscript for } \\
\text { publication }\end{array}$ & $\begin{array}{l}\text { DNP Student } \\
\text { Dr. Maxwell }\end{array}$ & June - July 2020 \\
\hline
\end{tabular}




\section{Concluding Essay:}

\section{Reflections on Growth in Advanced Practice Nursing Role}

As I reflect on the past three years, I never expected myself to grow and develop as a person and a healthcare professional as much as I have. I had the privilege of working as a hospital staff nurse and aesthetic nurse for a few years before I began my doctoral journey. My experience has only nurtured my passion and helped me realize that further academic growth would allow me to provide better care to my patients and their loved ones.

The University of San Diego (USD) gave me an opportunity to strengthen assessment skills and ignited a passion to continue to be a life-long learner. The doctoral program trained me to critically think and integrate evidence-based practice (EBP) into a clinical setting to improve patient outcomes. Through this program, I strengthened my foundation of knowledge in the ability to review journal articles and process protocols. I was challenged through my clinical experience to problem solve perplexing cases, which required additional education and care.

The doctor of nursing practice EBP project allowed me to utilize the skills taught in courses to successfully integrate a project that helped type II diabetes mellitus patients decrease their HgbAlc scores. I was able to see first-hand the effort patients were willing to put into managing their health with additional guidance and attention. The project and my experience in the program reinforced my passion as a nurse in treating patients and providing sustainable health care to those that need it the most.

Each professor at USD played an essential role in guiding me as a family nurse practitioner, always stimulating my peers and I to critically think through case studies, incorporating pathophysiology, treatment selection, and additional knowledge obtained from the courses. I am truly honored to be a USD alumnus and can confidently say that the program 
enabled me to make a greater difference and contribution to my patients, community, and the profession of Nursing. 


\section{Appendix A}

\section{IRB Approval}

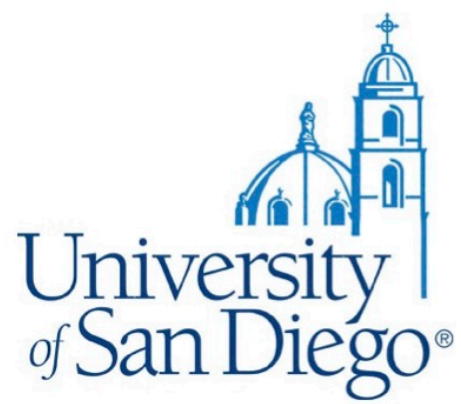

Sep 10, 2019 11:58 AM PDT

Nishita Patolia

Hahn School of Nursing \& Health Science

Re: Exempt - Initial - IRB-2020-3, Effects of Standardized Self-Care Behavior Education on Self-Efficacy Outcomes in Type II Diabetes Mellitus

Dear Nishita Patolia:

The Institutional Review Board has rendered the decision below for IRB-2020-3, Effects of Standardized Self-Care Behavior Education on Self-Efficacy Outcomes in Type II Diabetes Mellitus .

Decision: Exempt

Selected Category: Category 4. Secondary research for which consent is not required: Secondary research uses of identifiable private information or identifiable biospecimens, if at least one of the following criteria is met:

(i) The identifiable private information or identifiable biospecimens are publicly available;

(ii) Information, which may include information about biospecimens, is recorded by the investigator in such a manner that the identity of the human subjects cannot readily be ascertained directly or through identifiers linked to the subjects, the investigator does not contact the subjects, and the investigator will not re-identify subjects;

(iii) The research involves only information collection and analysis involving the investigator's use of identifiable health information when that use is regulated under 45 CFR parts 160 and 164, subparts $A$ and $E$, for the purposes of "health care operations" or "research" as those terms are defined at 45 CFR 164.501 or for "public health activities and purposes" as described under 45 CFR 164.512(b); or

(iv) The research is conducted by, or on behalf of, a Federal department or agency using government-generated or government-collected information obtained for nonresearch activities, if the research generates identifiable private information that is or will be maintained on information technology that is subject to and in compliance with section 208(b) of the E-Government Act of 2002, 44 U.S.C. 3501 note, if all of the identifiable private information collected, used, or generated as part of the activity will be maintained in systems of records subject to the Privacy Act of 1974, 5 U.S.C. 552a, and, if applicable, the information used in the research was collected subject to the Paperwork Reduction Act of 1995, 44 U.S.C. 3501 et seq.

Findings: None 
Research Notes:

Internal Notes:

Note: We send IRB correspondence regarding student research to the faculty advisor, who bears the ultimate responsibility for the conduct of the research. We request that the faculty advisor share this correspondence with the student researcher.

The next deadline for submitting project proposals to the Provost's Office for full review is N/A. You may submit a project proposal for expedited or exempt review at any time.

Sincerely,

Dr. Thomas R. Herrinton

Administrator, Institutional Review Board

Office of the Vice President and Provost

Hughes Administration Center, Room 214

5998 Alcalá Park, San Diego, CA 92110-2492

Phone (619) 260-4553 • Fax (619) 260-2210 • www.sandiego.edu 



\title{
Appendix C
}

\section{Poster Abstract with Letter of Acceptance to Conference}

\section{California Association for Nurse Practitioners Abstract}

Effects of Standardized Self-Care Behavior Education on Self-Efficacy Outcomes in Type II

\author{
Diabetes Mellitus
}

An evidenced-based practice (EBP) project will be implemented in a primary care clinic in Ramona, California. Implementation will focus on Type II Diabetes Mellitus (T2DM) selfmanagement through nursing education, focusing on self-efficacy and medication adherence guided by the American Association of Diabetes Educators 7 Self Care Behaviors (AADE7). The goal of this intervention is to decrease Hemoglobin A1c (HgbA1c) to less than $7 \%$ and increase medication adherence and self-efficacy by $20 \%$. A HgbA1c blood value will be obtained before the education has been provided and 3 months post-education. HgbA1c will continue to be monitored every three months for the rest of the year to ensure long term project success. The Stanford Patient Self-Efficacy Tool questionnaire will be given before each appointment and again after education has been provided by the DNP student. Participant will receive diabetes management education according to their pre-questionnaire results. Education can include healthy eating, medication adherence, exercise, healthy coping, and reducing risks. Support will be given through telephone follow-ups one month after the initial education and time will provided to answer any questions or concerns the patient has. Self-Efficacy results will be entered as an individual value into a spreadsheet and data will be aggregated averaging scores for pre- and post-tests. A percent change in $\mathrm{HgbA1c}$ values will also be examined to analyze the outcome data. The return on investment will be $579.1 \%$ profitability, as an individual can save \$4,910 with controlled Type II Diabetes Mellitus (Dall et al., 2016). 


\section{California Association for Nurse Practitioners Letter of Acceptance}

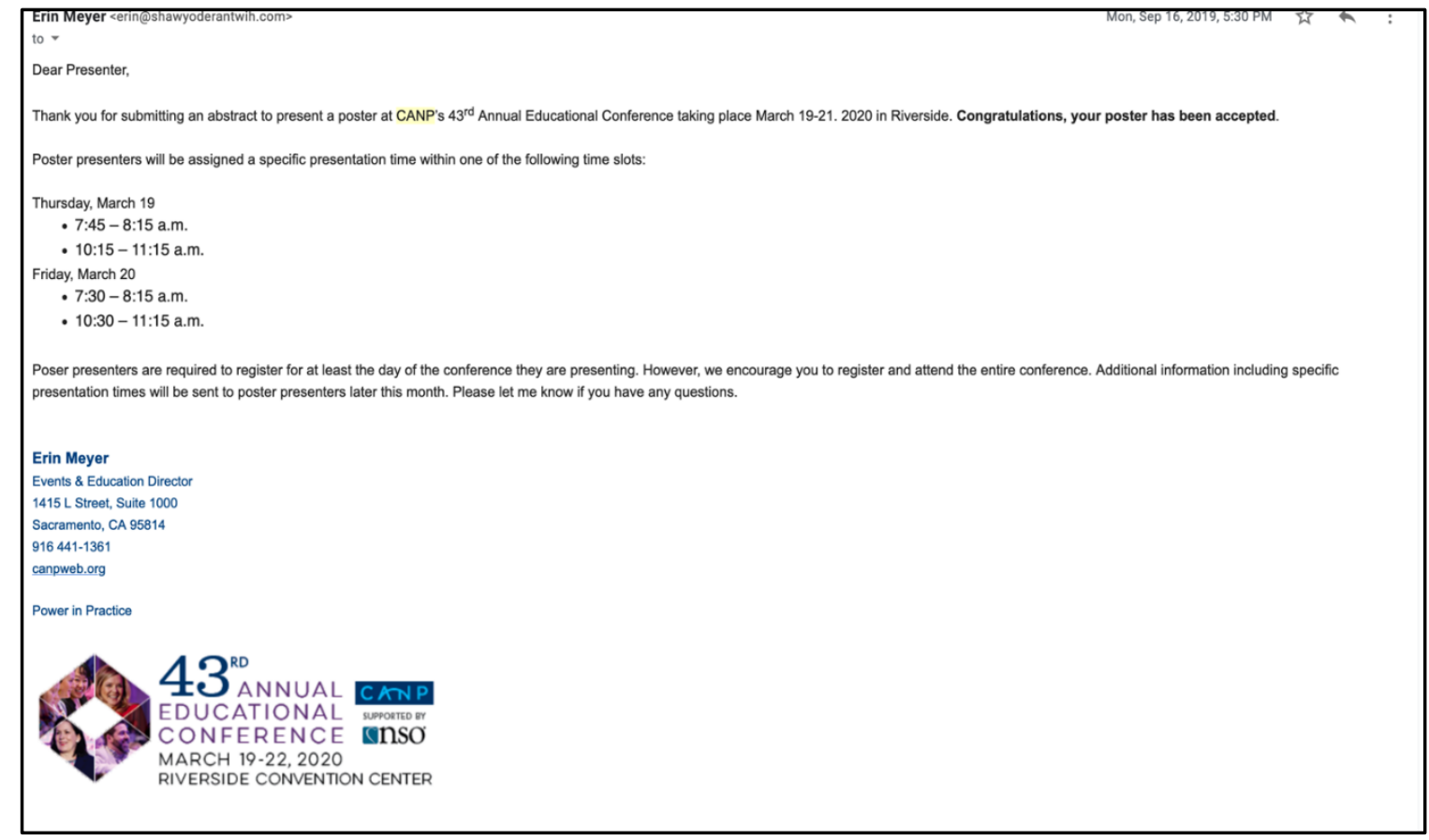




\section{Appendix D}

\section{Poster Presentation}

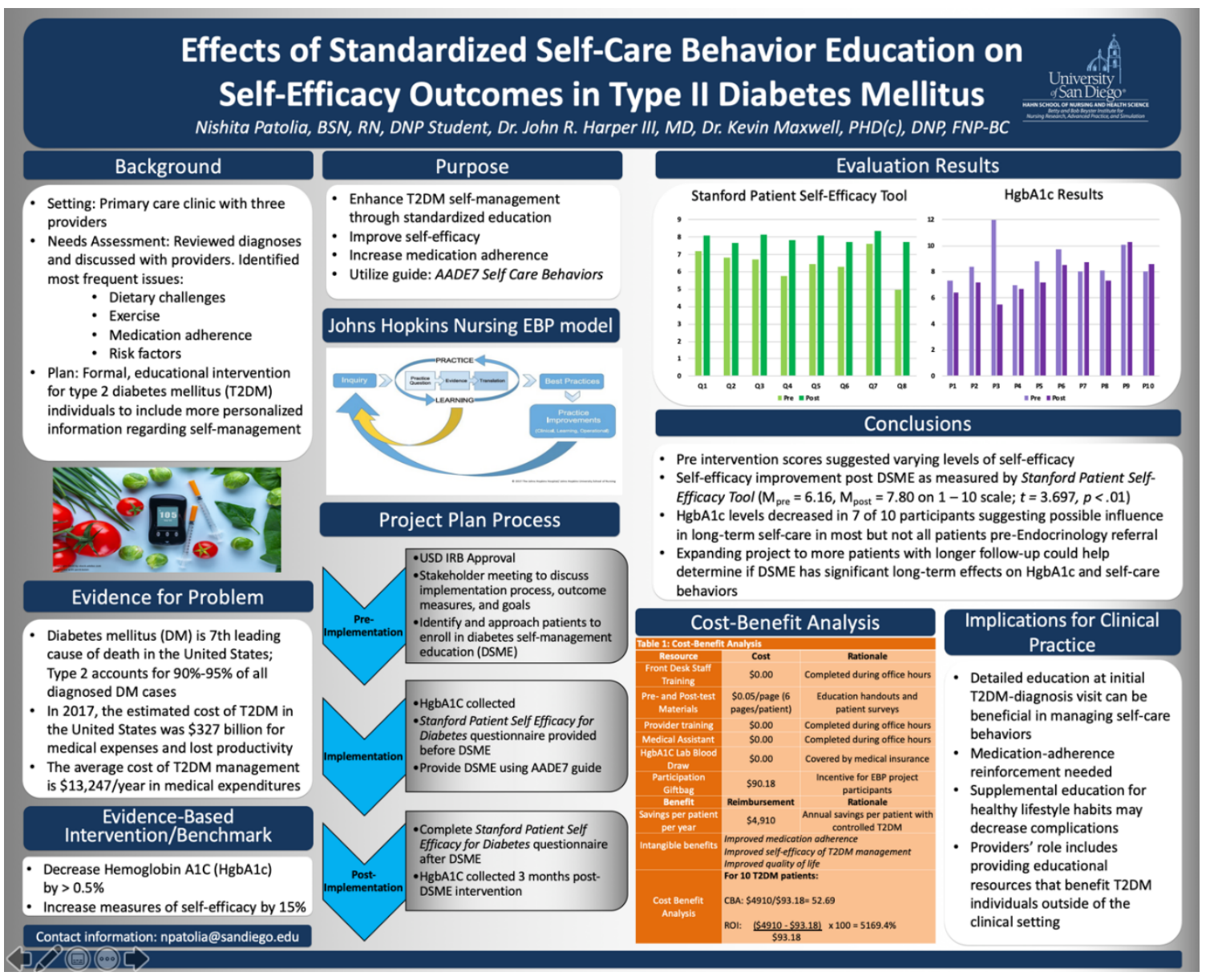


Appendix E

PowerPoint Stakeholder Presentation

Effects of Standardized Self-Care Behavior Education on Self-Efficacy Outcomes in Type II Diabetes Mellitus

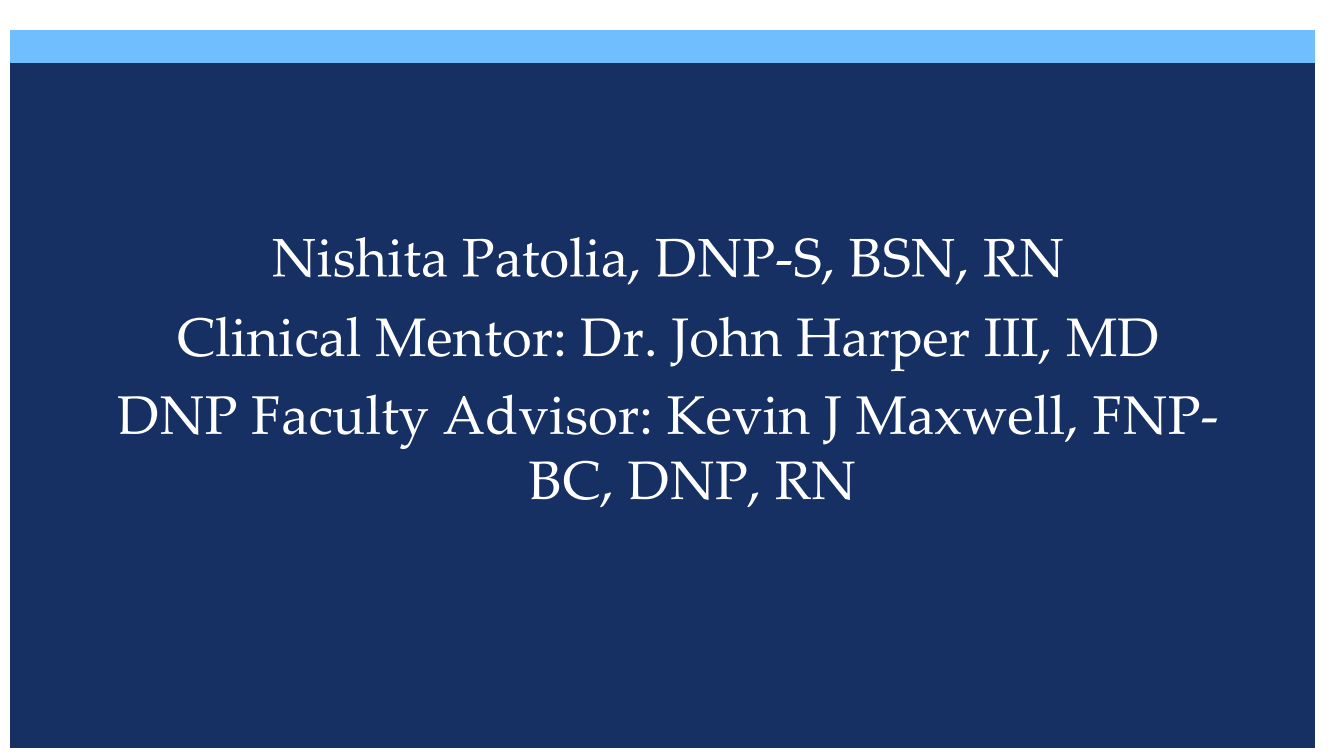

\section{Background \& Significance}

- Diabetes Mellitus: $7^{\text {th }}$ leading cause of death in the United States ${ }^{2}$

- $\quad$ Type 2 accounts for $90 \%-95 \%$ of all diagnosed DM cases

- $\quad$ Estimated cost of type II diabetes mellitus $(\mathrm{T} 2 \mathrm{DM})$ in the United States $=\$ 327$ billion for medical expenses and lost productivity in $2017^{11}$

- The average cost of T2DM management (per patient) is $\$ 13,247$ / year in medical expenditures $^{11}$

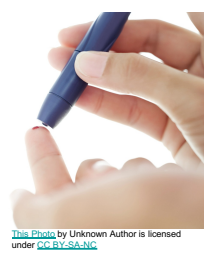




\section{Background \& Significance}

- Uncontrolled diabetes: \#1 cause of kidney failure, lower-limb amputations, and adult blindness ${ }^{2}$

- Lifestyle factors that affect the probability of developing T2DM:

- Overweight

- Physical inactivity

- Age (over 45 years)

- Family member with the disease

- Gestational diabetes during pregnancy

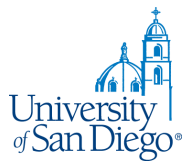

\section{Needs Assessment}

- $\quad$ Reviewed diagnoses and discussed with providers

- Identified most frequent issues:

- Dietary challenges

- Exercise

- Medication adherence

- Risk factors 


\section{Purpose}
Enhance T2DM self-management through standardized education

Improve self-efficacy

Increase medication adherence

Utilize guide: AADE7 Self Care Behaviors

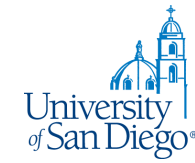

\section{Evidence-based Benchmark}

- $\quad$ Decrease Hemoglobin A1C (HgbA1c) by $>0.5 \%$

- Increase measures of self-efficacy by $15 \%$
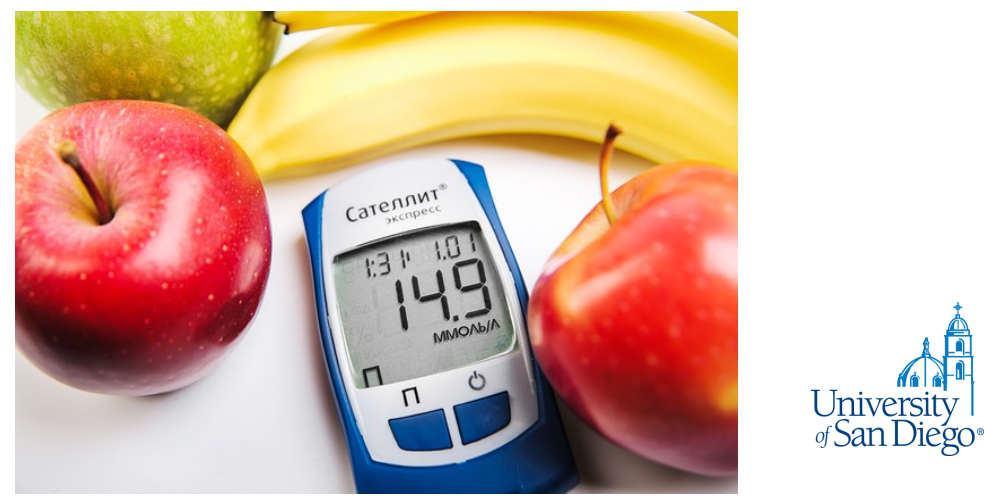


\section{Johns Hopkins Nursing EBP Model}

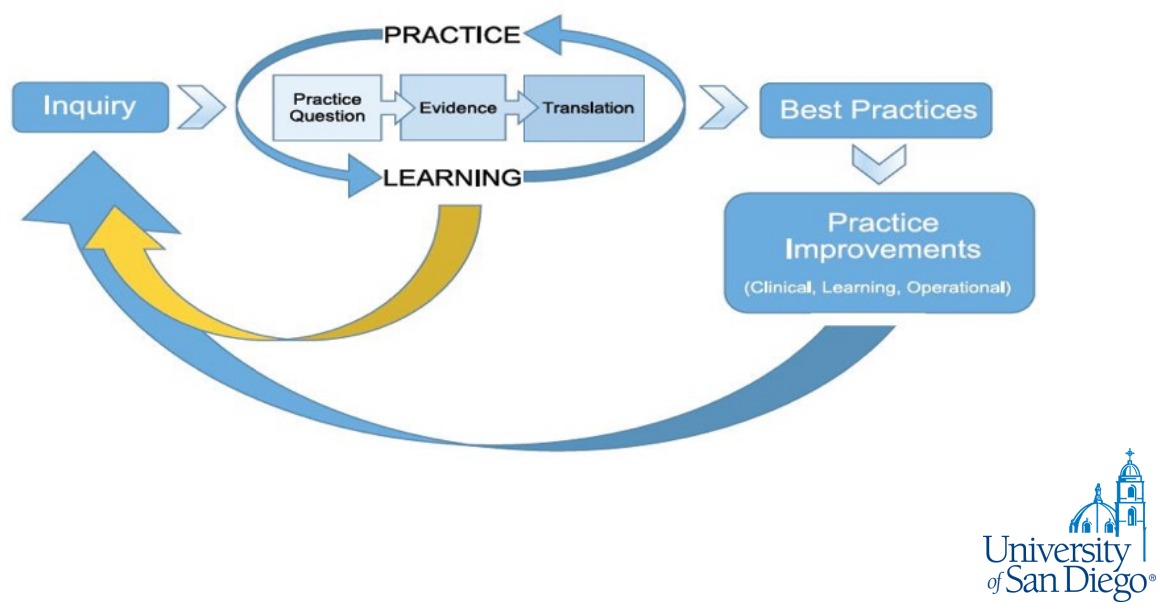

\section{Evidence-based Interventions}

-Diabetes Self-Management Education (DSME)

-Patient education utilizing the 7 self-care behaviors

from AADE7: 60 minutes

-Patient support: Telephone follow-up call 1 month post-DSME

-Stanford Patient Education Resource Center's Self-Efficacy for Diabetes questionnaire (SPSE). (determine confidence in doing certain activities)

-Pre- and post-DSME

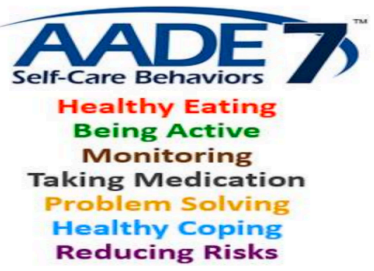




\section{Synthesis of Evidence}

- Standardized care leads to HgbA1c improvement and can lower blood pressure and cholesterol ${ }^{2}$

- Followed for one year post-intervention

- Showed that overall patient wellness did not decline over time compared to comparison group

- Increased contact time $=$ increased positive effects of education ${ }^{9}$

- Benefits may decline 1-3 months after the intervention ceases

- Long-term follow-up is necessary to support glycemic control and benefits of the self-management education

- A nurse-led consultation-based intervention increased patient motivation by asking patients to write down andiversity form action plans to improve self-efficacy ${ }^{5}$

\section{Synthesis of Evidence}

- A nurse-led consultation-based intervention increased patient motivation by asking patients to write down and form action plans to improve self-efficacy ${ }^{5}$

- An average HgbA1c change of $0.76 \%$ was seen during immediate follow-up, but a 23.6-hour duration of contact time between the educator and patient is necessary for every $1 \%$ decrease in $\mathrm{HgbA1}{ }^{9}$

- Patients with improved self-efficacy following education intervention were seen to have fewer hospitalization and emergency department visits as compared to a control group $^{10}$ 


\section{Project Plan Process}

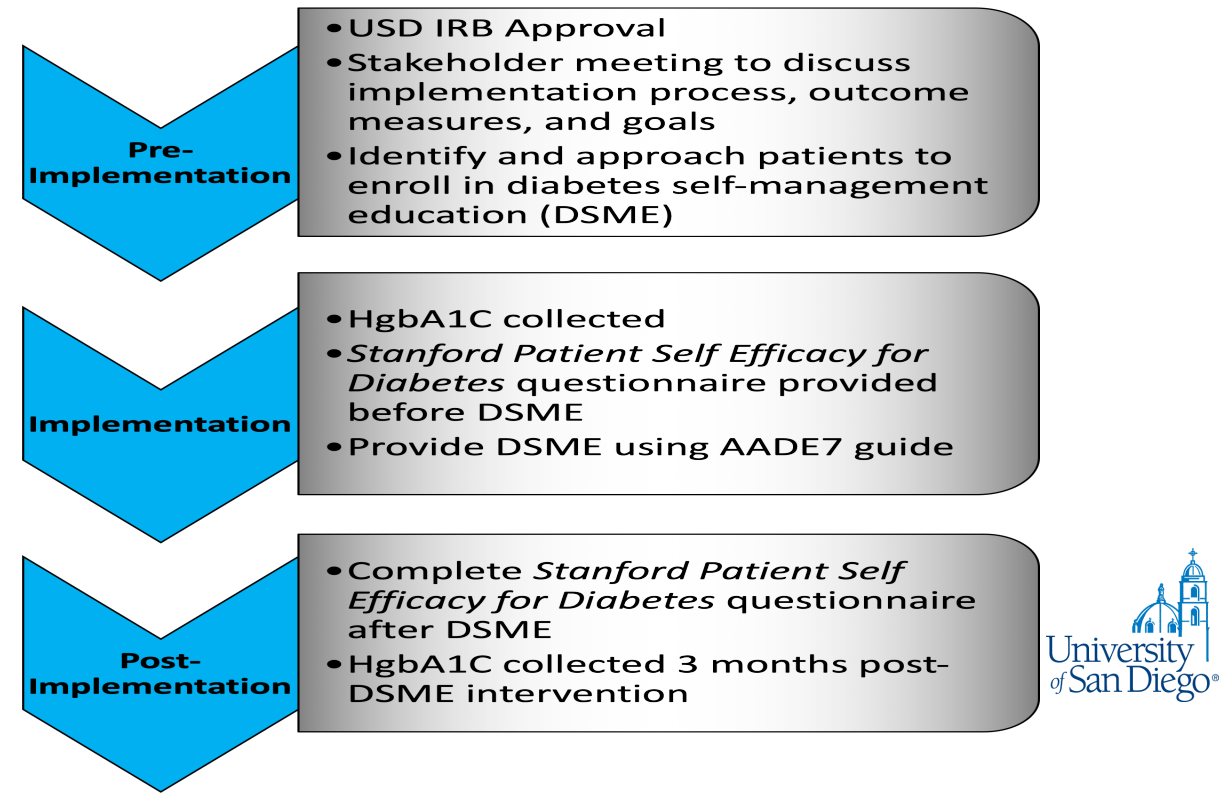

\section{EBP Project Flyer}

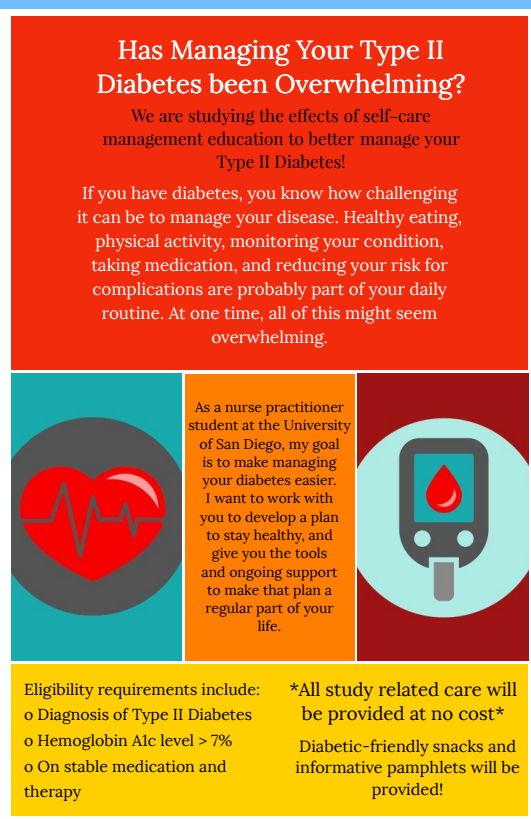




\section{Results}

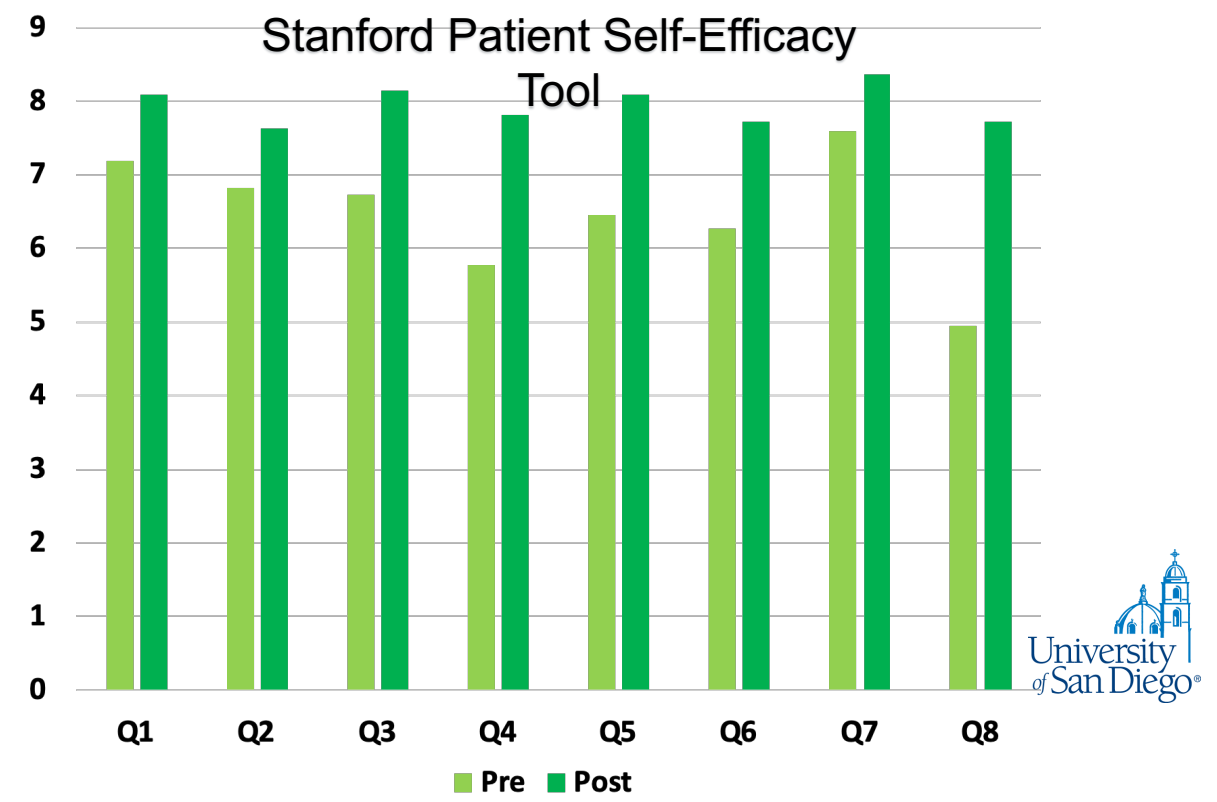

\section{Results}

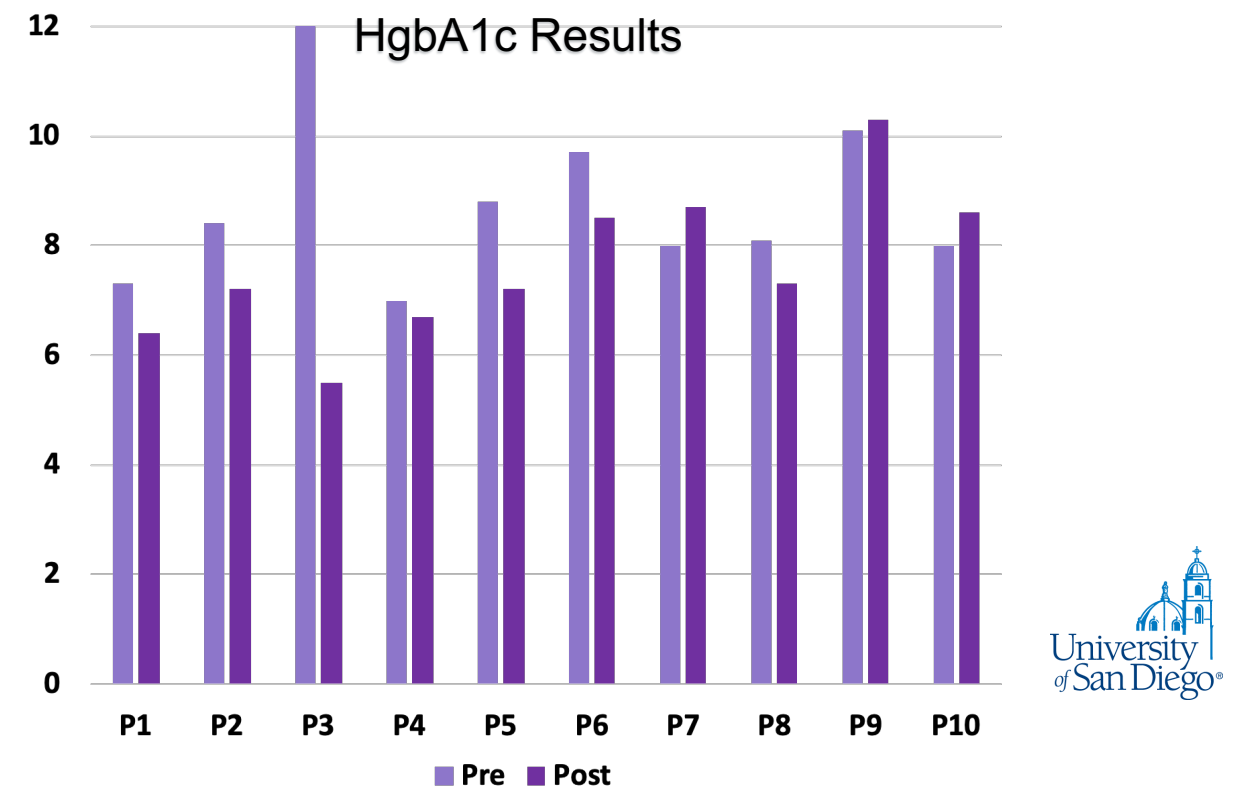




\section{Cost-Benefit Analysis}

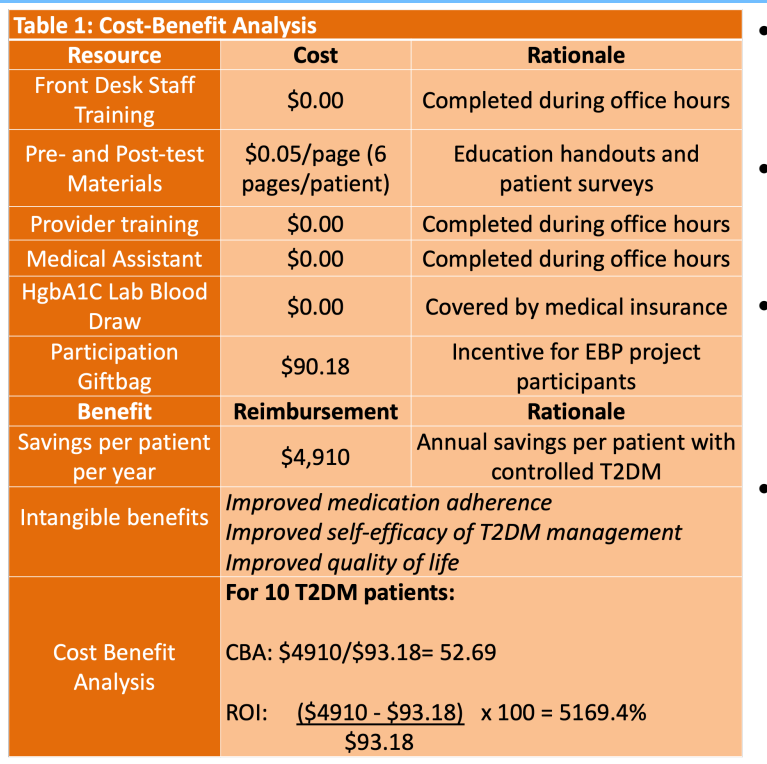

- $\$ 93.18=$ cost of participation giftbag and handout materials

- $\$ 4,910=$ annual savings / patients with controlled T2DM ${ }^{3}$

- For every $\$ 93.18$ spent on DSME, there will be a benefit of annual savings of $\$ 4910$.

- Every participant in the intervention, will see a 52.69-fold in cost savings. University of San Diego

\section{Conclusions}

- $\quad$ Pre intervention scores suggested varying levels of self- 든. efficacy

- $\quad$ Self-efficacy improvement post DSME as measured by Stanford Patient Self-Efficacy Tool $\left(\mathrm{M}_{\text {pre }}=6.16, \mathrm{M}_{\text {post }}=7.80\right.$ on 1 -10 scale; $t=3.697, p<.01$ )

- $\quad H g b A 1 c$ levels decreased in 7 of 10 participants suggesting possible influence in long-term self-care in most but not all patients pre-Endocrinology referral

- $\quad$ Expanding project to more patients with longer follow-up could help determine if DSME has significant long-termiversity effects on HgbA1c and self-care behaviors 


\section{Implications for Clinical Practice}

- Detailed education at initial T2DM-diagnosis visit can be beneficial in managing self-care behaviors

- Medication-adherence reinforcement needed

- Supplemental education for healthy lifestyle habits may decrease complications

- $\quad$ Providers' role includes providing educational resources that benefit T2DM individuals outside of the clinical setting

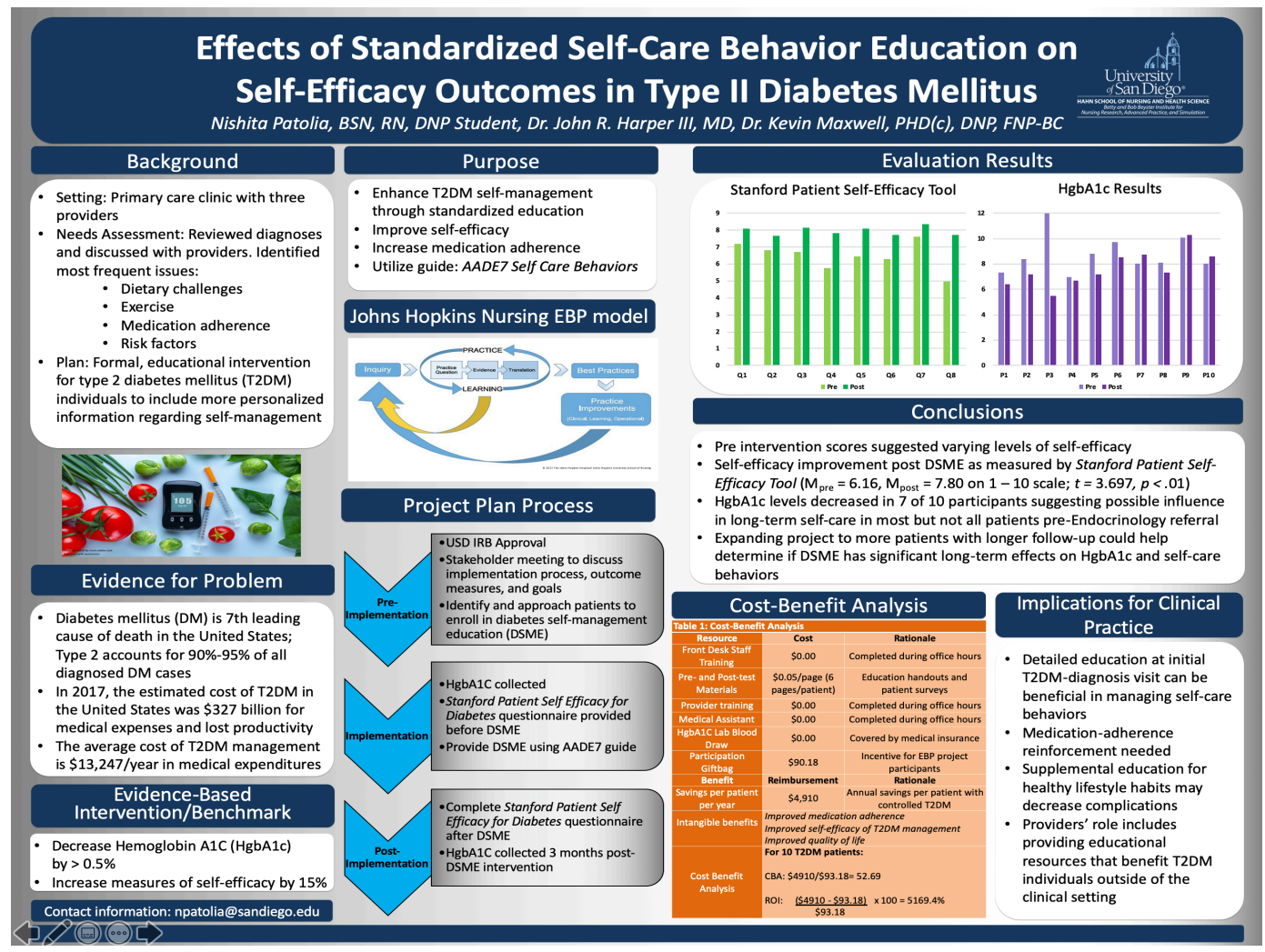




\section{References}

1. Brown, S. A., \& Hanis, C. L. (1999). Culturally competent diabetes education for Mexican Americans: The Starr County study. The Diabetes Educator, 25(2), 226-236. doi:10.1177/014572179902500208

2. Centers for Disease Control and Prevention. (2017). National diabetes statistics report.

https:// www.cdc.gov/diabetes/pdfs/data/statistics/national-diabetes-statistics-report.pdf

3. Dall, T. M., Yang, W., Halder, P., Franz, J., Byrne, E., Semilla, A. P., . . . Stuart, B. (2016). Type 2 diabetes detection and management among insured adults. Population Health Metrics, 14, 43. doi:10.1186/s12963-016-0110-4

4. Dang, D., \& Dearholt, S. (2017). Johns Hopkins nursing evidence-based practice: Model and guidelines (3rd ed). Indianapolis, IN: Sigma Theta Tau International.

5. Farmer, A., Hardeman, W., Hughes, D., Prevost, A. T., Kim, Y., Craven, A., ... Kinmonth, A.-L. (2012). An explanatory randomised controlled trial of a nurse-led, consultation-based intervention to support patients with adherence to taking glucose lowering medication for type 2 diabetes. BMC Family Practice, 13(1), 30. doi:10.1186/1471-2296$13-30$

6. Flode, M., Iversen, M. M., Aarflot, M., \& Haltbakk, J. (2017). Lasting impact of an implemented self-management programme for people with type 2 diabetes referred from primary care: a one-group, before-after design. Scandinavian Journal of Caring Science. 31(4), 789-795. doi:10.1111/scs.12398

7. Fokkens, A. S., Wiegersma, P. A., Beltman, F. W., \& Reijneveld, S. A. (2011). Structured primary care for type 2 diabetes has positive effects on clinical outcomes. Journal of Evaluation in Clinical Practice, 17(6), 1083-1088. doi:10.1111/j.1365-2753.2010.01466.x

8. Mayo Clinic. (2019). Type 2 diabetes - Symptoms and causes. Retrieved from https:/ / www.mayoclinic.org/diseases-

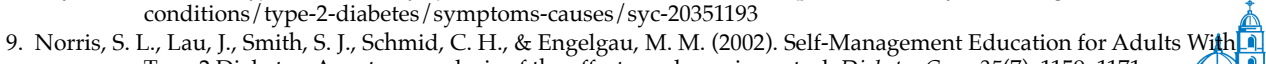
Type 2 Diabetes: A meta- analysis of the effect on glycemic control. Diabetes Care, 25(7), 1159-1171. Af it doi:10.2337/ diacare.25.7.1159

University

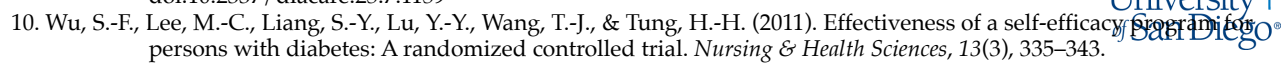
doi:10.1111/j.1442-2018.2011.00625.x

11. Yang, W., Dall, T. M., Beronjia, K. Lin, J., Semilla, A. P., Chakrabarti, R. \& Hogan, P. F. Economic costs of diabetes in the U.S. in 2017. (2018). Diabetes Care, 41(5), 917. doi:10.2337/ dci18-0007

\section{Questions?}

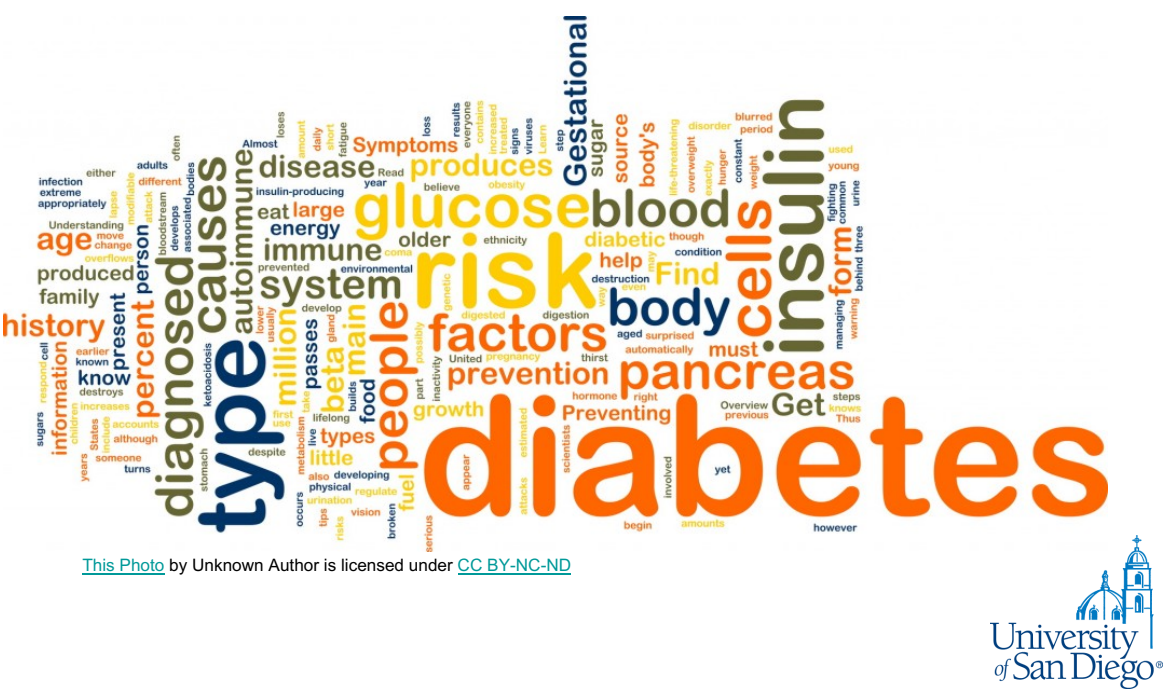


Appendix F

DNP Program Outcomes Exemplars

\begin{tabular}{|c|c|c|}
\hline $\begin{array}{c}\text { AACN DNP Essentials \& NONPF } \\
\text { Competencies }\end{array}$ & USD DNP Program Objectives & $\begin{array}{c}\text { Exemplars } \\
\text { Provide bulleted exemplars that } \\
\text { demonstrates achievement of each } \\
\text { objective }\end{array}$ \\
\hline $\begin{array}{l}\text { DNP Essential I: Scientific } \\
\text { Underpinnings for Practice } \\
\text { NONPF: Scientific Foundation } \\
\text { Competencies } \\
\text { The scientific foundation of nursing } \\
\text { practice has expanded and includes a } \\
\text { focus on both the natural and social } \\
\text { sciences including human biology, } \\
\text { genomics, science of therapeutics, } \\
\text { psychosocial sciences, as well as the } \\
\text { science of complex organizational } \\
\text { structures. In addition, philosophical, } \\
\text { ethical, and historical issues inherent in } \\
\text { the development of science create a } \\
\text { context for the application of the natural } \\
\text { and social sciences. }\end{array}$ & $\begin{array}{l}\text { 2. Synthesize nursing and other scientific } \\
\text { and ethical theories and concepts to create } \\
\text { a foundation for advanced nursing } \\
\text { practice. }\end{array}$ & $\begin{array}{l}\text { Fall 2017: } \\
\text { - } \quad \text { Utilized the Omaha model for } \\
\text { guidance in formulating a PICO } \\
\text { question in Evidence-Based } \\
\text { Synthesis of Asthma Action Plan } \\
\text { presentation } \\
\text { (DNPC611/DNPC626) } \\
\text { Summer 2018: } \\
\text { - Narrative reflection on self- } \\
\text { awareness, engagement with } \\
\text { others, and making meaning } \\
\text { (DNPC610) } \\
\text { Spring 2019: } \\
\text { - Logic Model used to outline EBP } \\
\text { (DNPC686) } \\
\text { Johns Hopkins model selected to } \\
\text { guide DNP EBP project to } \\
\text { improve quality care (DNPC686) }\end{array}$ \\
\hline
\end{tabular}




\begin{tabular}{|c|c|c|}
\hline $\begin{array}{c}\text { AACN DNP Essentials \& NONPF } \\
\text { Competencies }\end{array}$ & USD DNP Program Objectives & $\begin{array}{c}\text { Exemplars } \\
\text { Provide bulleted exemplars that } \\
\text { demonstrates achievement of each } \\
\text { objective }\end{array}$ \\
\hline $\begin{array}{l}\text { DNP Essential II: Organizational \& } \\
\text { System Leadership for Quality } \\
\text { improvement and Systems Thinking } \\
\text { NONPF: Leadership } \\
\text { Competencies/Health Delivery System } \\
\text { Competencies } \\
\text { Advanced nursing practice includes an } \\
\text { organizational and systems leadership } \\
\text { component that emphasizes practice, } \\
\text { ongoing improvement of health outcomes, } \\
\text { and ensuring patient safety. Nurses should } \\
\text { be prepared with sophisticated expertise } \\
\text { in assessing organizations, identifying } \\
\text { system's issues, and facilitating } \\
\text { organization-wide changes in practice } \\
\text { delivery. This also requires political skills, } \\
\text { systems thinking, and the business and } \\
\text { financial acumen needed for the analysis } \\
\text { of the practice quality and costs. }\end{array}$ & $\begin{array}{l}\text { 5. Design, implement, and evaluate ethical } \\
\text { health care delivery systems and } \\
\text { information systems that meet societal } \\
\text { needs and ensure accountability for } \\
\text { quality outcomes. }\end{array}$ & $\begin{array}{l}\text { Spring 2018: } \\
\text { - } \quad \text { Analyzed and applied strategic } \\
\text { management principles } \\
\text { demonstrated by Clemson Nursing } \\
\text { Home in a case study presentation } \\
\text { (DNPC626) } \\
\text { Spring 2019: } \\
\text { - Johns Hopkins model selected to } \\
\text { guide DNP EBP project to } \\
\text { improve quality care (DNPC686) } \\
\text { Summer 2019: } \\
\text { - DNPC630 narrative reflective } \\
\text { evaluating care delivered during } \\
\text { clinical experience in VA } \\
\text { Healthcare System (NPTC605) }\end{array}$ \\
\hline $\begin{array}{l}\text { DNP Essential III: Clinical Scholarship } \\
\text { \& Analytical Methods for Evidence- } \\
\text { Based Practice }\end{array}$ & $\begin{array}{l}\text { 4. Incorporate research into practice } \\
\text { through critical appraisal of existing } \\
\text { evidence, evaluating practice outcomes, } \\
\text { and developing evidence-based practice } \\
\text { guidelines. }\end{array}$ & $\begin{array}{l}\text { Fall 2017: } \\
\text { - } \quad \text { Synthesized and critiqued } \\
\text { evidenced in research paper } \\
\text { "Subjective perceived impact of } \\
\text { Tai Chi training on physical and }\end{array}$ \\
\hline
\end{tabular}




\begin{tabular}{|c|c|c|}
\hline $\begin{array}{c}\text { AACN DNP Essentials \& NONPF } \\
\text { Competencies }\end{array}$ & USD DNP Program Objectives & $\begin{array}{c}\text { Exemplars } \\
\text { Provide bulleted exemplars that } \\
\text { demonstrates achievement of each } \\
\text { objective }\end{array}$ \\
\hline $\begin{array}{l}\text { NONPF: Quality } \\
\text { Competencies/Practice Inquiry } \\
\text { Competencies } \\
\text { Scholarship and research are the } \\
\text { hallmarks of doctoral education. Although } \\
\text { basic research is viewed as the first and } \\
\text { most essential form of scholarly activity, } \\
\text { an enlarged perspective of scholarship } \\
\text { has emerged through alternative } \\
\text { paradigms that involve more than } \\
\text { discovery of new knowledge. These } \\
\text { paradigms recognize: (2) the scholarship } \\
\text { of discovery and integration "reflects the } \\
\text { investigative and synthesizing traditions } \\
\text { of academic life;" (2) scholars give } \\
\text { meaning to isolated facts and making } \\
\text { connections across disciplines through the } \\
\text { scholarship of integration; and (3) the } \\
\text { scholar applies knowledge to solve a } \\
\text { problem via the scholarship of application } \\
\text { that involves the translation of research } \\
\text { into practice and dissemination and } \\
\text { integration of new knowledge. }\end{array}$ & & $\begin{array}{l}\text { mental health among community } \\
\text { older adults at risk for ischemic } \\
\text { stroke: a qualitative study" } \\
\text { (DNPC611) } \\
\text { - } \\
\text { Developed a secondary screening } \\
\text { program for Type II Diabetes } \\
\text { Mellitus (DNPC625) } \\
\text { - Analyzed pathophysiology of } \\
\text { Peptic Ulcer Disease, Anemia, } \\
\text { Genetics, Diabetes, Urinary Tract } \\
\text { Infection, Hypertension, and } \\
\text { systemic lupus erythematous } \\
\text { including evidence-based research } \\
\text { in Clinical Ground Rounds } \\
\text { discussion (APNC520) } \\
\text { Spring 2018: } \\
\text { Synthesized and disseminated } \\
\text { evidence-based research in } \\
\text { Complementary and Alternative } \\
\text { Medicine Modalities Presentation: } \\
\text { Ginger (APNC523) } \\
\text { Fall 2018: } \\
\text { Developed evidence-based } \\
\text { manuscript to prepare for } \\
\text { submission "Bipolar Disorder I \& }\end{array}$ \\
\hline
\end{tabular}




\begin{tabular}{|c|c|c|}
\hline $\begin{array}{c}\text { AACN DNP Essentials \& NONPF } \\
\text { Competencies }\end{array}$ & USD DNP Program Objectives & $\begin{array}{c}\text { Exemplars } \\
\text { Provide bulleted exemplars that } \\
\text { demonstrates achievement of each } \\
\text { objective }\end{array}$ \\
\hline & & $\begin{array}{l}\text { II: Review of Pathogenesis, } \\
\text { Clinical Findings and Treatment" } \\
\text { (DNPC622) } \\
\text { Spring 2019: } \\
\text { - DNPC630 reflective narrative to } \\
\text { evaluate standard practice in a } \\
\text { family practice health setting and } \\
\text { administration of steroids for } \\
\text { osteoarthritis (NPTC604) } \\
\text { Summer 2019: } \\
\text { - Synthesized and evaluated } \\
\text { evidence and developed proposal } \\
\text { for DNP Scholarly Project }\end{array}$ \\
\hline $\begin{array}{l}\text { DNP Essential IV: Information } \\
\text { Systems/Technology \& Patient Care } \\
\text { Technology for Improvement \& } \\
\text { Transformation of Health Care } \\
\text { NONPF: Technology \& Information } \\
\text { Literacy Competencies } \\
\text { DNP graduates are distinguished by their } \\
\text { abilities to use information } \\
\text { systems/technology to support and }\end{array}$ & $\begin{array}{l}\text { 7. Incorporate ethical regulatory, and legal } \\
\text { guidelines in the delivery of health care } \\
\text { and the selection, use, and evaluation of } \\
\text { information systems and patient care } \\
\text { technology. }\end{array}$ & $\begin{array}{l}\text { Fall 2017: } \\
\text { - } \quad \text { Obtained Biomedical Research } \\
\text { Human Certification- } \\
\text { Basic/Refresher Course through } \\
\text { CITI (DNPC625) } \\
\text { Spring 2018: } \\
\text { - Utilize skills learned through } \\
\text { Excel Educator to formulate an } \\
\text { analysis of the increase in }\end{array}$ \\
\hline
\end{tabular}




\begin{tabular}{|c|c|c|}
\hline $\begin{array}{c}\text { AACN DNP Essentials \& NONPF } \\
\text { Competencies }\end{array}$ & USD DNP Program Objectives & $\begin{array}{c}\text { Exemplars } \\
\text { Provide bulleted exemplars that } \\
\text { demonstrates achievement of each } \\
\text { objective }\end{array}$ \\
\hline $\begin{array}{l}\text { improve patient care and health care } \\
\text { systems, and provide leadership within } \\
\text { health care systems and/or academic } \\
\text { settings. Knowledge and skills related to } \\
\text { information systems/technology and } \\
\text { patient care technology prepare the DNP } \\
\text { graduates apply new knowledge, manage } \\
\text { individual and aggregate level } \\
\text { information, and assess the efficacy of } \\
\text { patient care technology appropriate to a } \\
\text { specialized area of practice along with the } \\
\text { design, selection, and use of information } \\
\text { systems/technology to evaluate programs } \\
\text { of care, outcomes of care, and care } \\
\text { systems. Information systems/technology } \\
\text { provide a mechanism to apply budget and } \\
\text { productivity tools, practice information } \\
\text { systems and decision supports, and web- } \\
\text { based learning or intervention tools to } \\
\text { support and improve patient care. }\end{array}$ & & $\begin{array}{l}\text { prevalence of Type II Diabetes in } \\
\text { the United States (DNPC540) } \\
\text { Fall 2019: } \\
\text { - Obtained USD IRB approval for } \\
\text { DNP EBP Project } \\
\text { - Implementation of DNP project in } \\
\text { primary care setting providing } \\
\text { diabetes self-management } \\
\text { education to improve self-efficacy } \\
\text { and HgbAlc outcomes }\end{array}$ \\
\hline $\begin{array}{l}\text { DNP Essential V: Health Care Policy } \\
\text { for Advocacy in Health Care } \\
\text { NONPF: Policy Competencies } \\
\text { Health care policy, whether created } \\
\text { through governmental actions, }\end{array}$ & $\begin{array}{l}\text { 3. Demonstrate leadership in collaborative } \\
\text { efforts to develop and implement policies } \\
\text { to improve health care delivery and } \\
\text { outcomes at all levels of professional } \\
\text { practice (institutional, local, state, } \\
\text { regional, national, and/or international). }\end{array}$ & $\begin{array}{l}\text { Fall 2017: } \\
\text { - Evaluate the socioeconomic } \\
\text { changes in correlation to the } \\
\text { increase in Type II Diabetes in the } \\
\text { United States (DNPC625) }\end{array}$ \\
\hline
\end{tabular}




\begin{tabular}{|c|c|c|}
\hline $\begin{array}{c}\text { AACN DNP Essentials \& NONPF } \\
\text { Competencies }\end{array}$ & USD DNP Program Objectives & $\begin{array}{c}\text { Exemplars } \\
\text { Provide bulleted exemplars that } \\
\text { demonstrates achievement of each } \\
\text { objective }\end{array}$ \\
\hline $\begin{array}{l}\text { institutional decision-making, or } \\
\text { organizational standards, creates a } \\
\text { framework that can facilitate or impede } \\
\text { the delivery of health care services or the } \\
\text { ability of the provider to engage in } \\
\text { practice to address health care needs. } \\
\text { Engagement in the process of policy } \\
\text { development is central to creating a } \\
\text { health care system that meets the needs of } \\
\text { its constituents. Political activism and the } \\
\text { commitment to policy development are } \\
\text { central elements of DNP practice. }\end{array}$ & & $\begin{array}{l}\text { Spring 2018: } \\
\text { - } \quad \text { Presentation and health policy } \\
\text { analysis of the Consensus Model } \\
\text { for APRN Regulation (DNPC648) } \\
\text { - } \text { Developed policy brief on } \\
\text { H.R.1634: Education and Training } \\
\text { for Health Act of } 2017 \\
\text { (DNPC648) } \\
\text { - Developed health policy analysis } \\
\text { scholarly paper for H.R.354: } \\
\text { Defund Planned Parenthood Act of } \\
\text { 2017 (DNPC648) } \\
\text { Spring 2020: } \\
\text { - Abstract submission and } \\
\text { acceptance for poster presentation } \\
\text { of DNP scholarly project at } 2020 \\
\text { California Association for Nurse } \\
\text { Practitioners Convention }\end{array}$ \\
\hline $\begin{array}{l}\text { DNP Essential VI: Interprofessional } \\
\text { Collaboration for Improving Patient \& } \\
\text { Population Health Outcomes } \\
\text { NONPF: Leadership Competencies }\end{array}$ & $\begin{array}{l}\text { 1. Demonstrate advanced levels of clinical } \\
\text { practice within defined ethical, legal, and } \\
\text { regulatory parameters in designing, } \\
\text { implementing, and evaluating evidenced- } \\
\text { based, culturally competent therapeutic } \\
\text { interventions for individuals or } \\
\text { aggregates. }\end{array}$ & $\begin{array}{l}\text { Fall 2019: } \\
\text { - Shared evidenced-based literature } \\
\text { with clinicals in primary care } \\
\text { setting indicating need for EBP } \\
\text { project }\end{array}$ \\
\hline
\end{tabular}




\begin{tabular}{|c|c|c|}
\hline $\begin{array}{c}\text { AACN DNP Essentials \& NONPF } \\
\text { Competencies }\end{array}$ & USD DNP Program Objectives & $\begin{array}{c}\text { Exemplars } \\
\text { Provide bulleted exemplars that } \\
\text { demonstrates achievement of each } \\
\text { objective }\end{array}$ \\
\hline $\begin{array}{l}\text { Today's complex, multi-tiered health care } \\
\text { environment depends on the contributions } \\
\text { of highly skilled and knowledgeable } \\
\text { individuals from multiple professions. In } \\
\text { order to accomplish the IOM mandate for } \\
\text { safe, timely, effective, efficient, equitable, } \\
\text { and patient-centered care in this } \\
\text { environment, health care professionals } \\
\text { must function as highly collaborative } \\
\text { teams. DNPs have advanced preparation } \\
\text { in the interprofessional dimension of } \\
\text { health care that enable them to facilitate } \\
\text { collaborative team functioning and } \\
\text { overcome impediments to } \\
\text { interprofessional practice. DNP } \\
\text { graduates have preparation in methods of } \\
\text { effective team leadership and are } \\
\text { prepared to play a central role in } \\
\text { establishing interprofessional teams, } \\
\text { participating in the work of the team, and } \\
\text { assuming leadership of the team when } \\
\text { appropriate. }\end{array}$ & $\begin{array}{l}\text { 3. Demonstrate leadership in collaborative } \\
\text { efforts to develop and implement policies } \\
\text { to improve health care delivery and out } \\
\text { comes at all levels of professional practice } \\
\text { (institutional, local, state, regional, } \\
\text { national, and/or international). }\end{array}$ & $\begin{array}{l}\text { - Implementation of DNP project in } \\
\text { primary care setting providing } \\
\text { diabetes self-management } \\
\text { education to improve self-efficacy } \\
\text { and HgbA1c outcomes } \\
\text { Spring 2020: } \\
\text { - Abstract submission and } \\
\text { acceptance for poster presentation } \\
\text { of DNP scholarly project at } 2020 \\
\text { California Association for Nurse } \\
\text { Practitioners Convention }\end{array}$ \\
\hline $\begin{array}{l}\text { DNP Essential VII: Clinical Prevention } \\
\text { \& Population Health for Improving } \\
\text { Nation's Health } \\
\text { NONPF: Leadership Competencies }\end{array}$ & $\begin{array}{l}\text { 6. Employ a population health focus in the } \\
\text { design, implementation, and evaluation of } \\
\text { health care delivery systems that address } \\
\text { primary secondary, and tertiary levels of } \\
\text { prevention. }\end{array}$ & $\begin{array}{l}\text { Fall 2017: } \\
\begin{array}{l}\text { - } \\
\text { Presented a secondary screening } \\
\text { recommendation for Type II } \\
\text { Diabetes Mellitus (DNPC625) }\end{array}\end{array}$ \\
\hline
\end{tabular}




\begin{tabular}{|c|c|c|}
\hline $\begin{array}{c}\text { AACN DNP Essentials \& NONPF } \\
\text { Competencies }\end{array}$ & USD DNP Program Objectives & $\begin{array}{c}\text { Exemplars } \\
\text { Provide bulleted exemplars that } \\
\text { demonstrates achievement of each } \\
\text { objective }\end{array}$ \\
\hline $\begin{array}{l}\text { Consistent with national calls for action } \\
\text { and with the longstanding focus on health } \\
\text { promotion and disease prevention in } \\
\text { nursing, the DNP graduate has a } \\
\text { foundation in clinical prevention and } \\
\text { population health. This foundation } \\
\text { enables DNP graduates to analyze } \\
\text { epidemiological, biostatistical, } \\
\text { occupational, and environmental data in } \\
\text { the development, implementation, and } \\
\text { evaluation of clinical prevention and } \\
\text { population. }\end{array}$ & & $\begin{array}{l}\text { - } \begin{array}{l}\text { Evaluated and discussed current } \\
\text { health care gaps in diagnosis and } \\
\text { treatment of Asthma (DNPC626) }\end{array} \\
\text { Fall 2019: } \\
\text { - Identify type II diabetes mellitus } \\
\text { patients in the primary care clinic } \\
\text { and provide diabetes self- } \\
\text { management education } \\
\text { - Implementation of DNP scholarly } \\
\text { project to improve self-efficacy } \\
\text { and decrease HgbA1c levels }\end{array}$ \\
\hline $\begin{array}{l}\text { DNP Essential VIII: Advanced Nursing } \\
\text { Practice } \\
\text { NONPF: Independent Practice/Ethics } \\
\text { Competencies } \\
\text { The increased knowledge and } \\
\text { sophistication of health care has resulted } \\
\text { in the growth of specialization in nursing } \\
\text { in order to ensure competence in these } \\
\text { highly complex areas of practice. The } \\
\text { reality of the growth of specialization in } \\
\text { nursing practice is that no individual can }\end{array}$ & $\begin{array}{l}\text { 1. Demonstrate advanced levels of clinical } \\
\text { practice within defined ethical, legal, and } \\
\text { regulatory parameters in designing, } \\
\text { implementing, and evaluating evidence- } \\
\text { based, culturally competent therapeutic } \\
\text { interventions for individuals or } \\
\text { aggregates. }\end{array}$ & $\begin{array}{l}\text { Fall 2018: } \\
\text { Student Nurse Practitioner: } \\
\text { - Coastal Medical Weight Loss Centers } \\
\text { nurse practitioner Dr. Kathy James } \\
\text { (DNPC630) } \\
\text { - Interviewed and summarized health } \\
\text { promotion paper on individual patient } \\
\text { (APNC602) } \\
\text { - Complete and demonstrate physical } \\
\text { exam competencies in skills labs } \\
\text { (APNC521) }\end{array}$ \\
\hline
\end{tabular}




\begin{tabular}{|c|c|c|}
\hline $\begin{array}{c}\text { AACN DNP Essentials \& NONPF } \\
\text { Competencies }\end{array}$ & USD DNP Program Objectives & $\begin{array}{c}\text { Exemplars } \\
\text { Provide bulleted exemplars that } \\
\text { demonstrates achievement of each } \\
\text { objective }\end{array}$ \\
\hline $\begin{array}{l}\text { master all advanced roles and the } \\
\text { requisite knowledge for enacting these } \\
\text { roles. DNP programs provide preparation } \\
\text { within distinct specialties that require } \\
\text { expertise, advanced knowledge, and } \\
\text { mastery in one are of nursing practice. A } \\
\text { DNP graduate is prepared to practice in } \\
\text { an area of specialization within the larger } \\
\text { domain of nursing. }\end{array}$ & & $\begin{array}{l}\text { Spring 2019: } \\
\text { Student Nurse Practitioner: } \\
\text { - } \quad \text { Dr. John R. Harper III, MD a } \\
\text { Professional Corporation with Dr. } \\
\text { Harper (DNPC630) } \\
\text { - VA San Diego Healthcare System } \\
\text { with nurse practitioner Victoria Bailey } \\
\text { in Specialty Access Clinic (Diabetes } \\
\text { Mellitus) (DNPC630) } \\
\text { - VA San Diego Healthcare System } \\
\text { with nurse practitioner Victoria Bailey } \\
\text { in Specialty Access Clinic (Diabetes } \\
\text { Mellitus) (DNPC630) } \\
\text { Allureous LLC Medical Spa and } \\
\text { Clinic with nurse practitioner Dr. } \\
\text { Jenilyn Peros (DNPC630) } \\
\text { Summer 2019: } \\
\text { Student Nurse Practitioner: } \\
\text { - VA San Diego Healthcare System } \\
\text { Specialty Access Clinic (Diabetes } \\
\text { Mellitus) with nurse practitioner } \\
\text { Victoria Bailey (DNPC630) } \\
\text { VA San Diego Healthcare System } \\
\text { Internal Medicine with nurse }\end{array}$ \\
\hline
\end{tabular}




\begin{tabular}{|c|c|c|}
\hline $\begin{array}{c}\text { AACN DNP Essentials \& NONPF } \\
\text { Competencies }\end{array}$ & USD DNP Program Objectives & $\begin{array}{c}\text { Exemplars } \\
\text { Provide bulleted exemplars that } \\
\text { demonstrates achievement of each } \\
\text { objective }\end{array}$ \\
\hline & & $\begin{array}{l}\text { practitioner Karen Kupferman } \\
\text { (DNPC630) } \\
\text { - Implement use of evidence-based } \\
\text { literature to guide best practice for } \\
\text { Type II Diabetes DNP Project } \\
\text { - Consult with evidence-based resources } \\
\text { to guide clinical decision making } \\
\text { during clinical experiences } \\
\text { (UpToDate, Epocrates, Clinical } \\
\text { Practice Guidelines) } \\
\text { Fall 2019: } \\
\text { Student Nurse Practitioner: } \\
\text { - Planned Parenthood with Dr. Kyle } \\
\text { Bukowski MD (DNPC630) } \\
\text { - VA San Diego Healthcare System } \\
\text { Internal Medicine with nurse } \\
\text { practitioner Karen Kupferman } \\
\text { (DNPC630) } \\
\text { Spring 2020: } \\
\text { Student Nurse Practitioner: } \\
\text { - Sharp Rees-Stealy Medical Group } \\
\text { Dermatology with Dr. Curt Littler MD } \\
\text { (DNPC630) } \\
\text { Completion of DNP Manuscript } \\
\text { (DNPC630) }\end{array}$ \\
\hline
\end{tabular}




\section{DNP Program Outcomes and Exemplar Reflections}

In the last three years, I have grown and developed in the scholar and clinical roles as shown in the American Association of Colleges of Nursing (AACN) Doctor of Nursing Practice essentials and the National Organization of Nurse Practitioner Faculties (NONPF) competencies. Below are a few examples of how I accomplished the AACN essentials and NONPF competencies as a Doctor of Nursing Practice Student.

I would like to reflect on Doctor of Nursing Practice (DNP) Essential I, Scientific Underpinnings for Practice, and NONPF Competency, Scientific Foundation. In Fall 2017, I was given the opportunity to take Methods of Translational Science with Dr. Burkard. During this course, I learned about the first steps of writing an evidence-based practice (EBP) paper and developing a PICOT question. In this course, I wrote my first paper about a potential EBP project on Asthma Action Plans guided by the Omaha model. I also learned how to critique literature by performing a formal literature review. During Perspectives in Program Planning in Spring 2019, the Johns Hopkins model was chosen for guidance on my DNP EBP project to improve self-management in type II diabetes mellitus (T2DM) patients. At the end of the course, I created a poster presentation to present at California Association for Nurse Practitioners (CANP) and delivered an elevator speech about my DNP EBP project to the class.

I would like to reflect on DNP Essential II, Organizational \& System Leadership for Quality Improvement and Systems Thinking, and the NONPF Leadership and Health Delivery Systems Competency. In Fall 2017, I had the opportunity to take an epidemiology course with Dr. Barger where I wrote a paper developing a secondary screening program for T2DM. Dr. Maxwell's Advanced Pathophysiology course in Fall 2017 was a foundational piece in my DNP 
journey and was essential in managing various diseases throughout my clinical rotations. In Primary Care IIA of Spring 2019, I wrote a reflective narrative that evaluated standard practice in a family practice setting and administration of steroids for osteoarthritis.

Next, I would like to discuss DNP Essential III, Clinical Scholarship \& Analytical Methods for Evidence-Based Practice and NONPF Quality and Practice Inquiry Competencies. In Spring 2018, Introduction to Healthcare Informatics played a fundamental role in the data analysis of my final DNP EBP project. Excel Educator was integrated into this course, where I was able to formulate an analysis of the increase in prevalence of T2DM in the United States. In Fall 2019, I obtained USD IRB approval for the implementation of the DNP project in a primary care setting, providing diabetes self-management education to improve self-efficacy and HgbA1c outcomes.

I would like to discuss DNP Essential IV, Information Systems/Technology \& Patient Care Technology for Improvement \& Transformation of Health Care and NONPF Technology \& Information Literacy Competencies. I obtained Biomedical Research Human CertificationBasic/Refresher course through CITI in Fall 2017 to help me understand the ethical, regulatory, and legal guidelines of research. Health Policy Analysis was taken in Spring 2018, where I developed a policy brief on H.R.1634: Education and Training for Health Act on 2017. In this course, I also had the opportunity develop a health policy analysis scholarly paper for H.R.354: Defund Planned Parenthood Act of 2017. In this paper, which was also presented to the class, I analyzed the benefits of Planned Parenthood clinics in providing essential services outside of its controversial abortion service. I used statistical data and a discussion of Roe versus Wade of 1973 to support Planned Parenthood funding and support by the government. As a member of the 
California Association for Nurse Practitioners, I am able to stay up to date with current health care policies, such as full practice authority for nurse practitioners.

DNP Essential V, Health Care Policy for Advocacy in Health Care and NONPF Policy Competencies will be discussed next. I demonstrated leadership in collaborative efforts by submitting my abstract that was approved for poster presentation of DNP Scholarly project at the 2020 California Association for Nurse Practitioners convention. However, due to the pandemic the convention was cancelled. In Spring 2018, I presented the consensus model for advanced practice registered nurse (APRN) regulation in the course Health Policy Analysis. In the presentation, I discussed the uniformity of guidance between states for licensure, accreditation, certification, and education.

Next, I will discuss DNP Essential VI, Interprofessional Collaboration for Improving Patient and Population Health Outcomes \& NONPF Leadership Competencies. I demonstrated advanced levels of clinical practice by successfully implementing a DNP EBP project in a primary care setting by providing diabetes self-management education to improve self-efficacy and $\mathrm{HgbA1c}$ outcomes. Outcome improvement demonstrated that standardized diabetes management education can be beneficial in preventing long-term complications.

DNP Essential VII, Clinical Prevention \& Population Health for Improving Nation's Health and NONPF Leadership Competencies will be discussed next. During my epidemiology course in Fall 2017, I presented a plausible secondary screening recommendation for T2DM. During my clinical rotations, I was also able to implement primary, secondary, and tertiary levels of prevention to best manage patient care and wellbeing. Identifying T2DM patients for my EBP project also focused on comorbidity prevention by providing education and a thorough analysis of blood lab values. 
Next, I will be discussing the final essential, DNP Essential VIII, Advanced Nursing Practice and NONPF Independent Practice/Ethics Competencies. In Fall 2018, I was enrolled in APRN Physical Assessment and Diagnosis. Part of this course involved skills lab, where we were given opportunities to practice hands-on learning for every anatomical system. I was also given many opportunities for clinical rotations in various settings, such as internal medicine, dermatology, endocrinology, and family medicine. Totaling 1183 hours under the supervision of clinical preceptors and mentors, I was able to experience managing patients of all backgrounds and working with multidisciplinary teams. My knowledge as an APRN has evolved through these past three years. I am confident the coursework and education provided clinically and didactically will allow me to improve patient management as a nurse practitioner. 


\section{Appendix G}

\section{Other Supporting Documents}

\section{Has Managing Your Type II Diabetes been Overwhelming?}

We are studying the effects of self-care management education to better manage your Type II Diabetes!

If you have diabetes, you know how challenging it can be to manage your disease. Healthy eating, physical activity, monitoring your condition, taking medication, and reducing your risk for complications are probably part of your daily routine. At one time, all of this might seem

overwhelming.

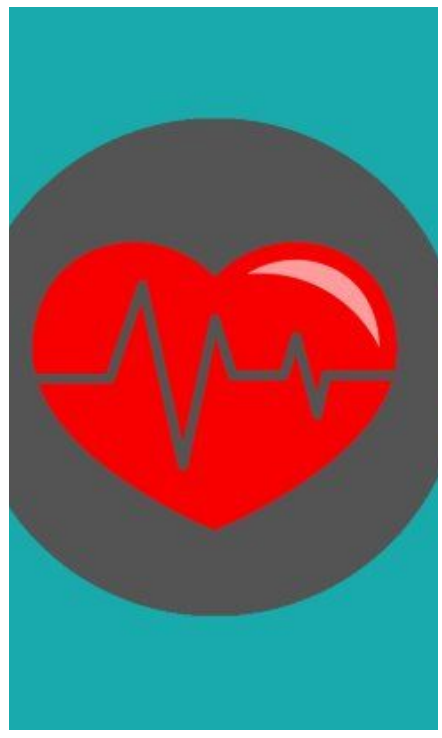

As a nurse practitioner student at the University of San Diego, my goal is to make managing your diabetes easier. I want to work with you to develop a plan to stay healthy, and give you the tools and ongoing support to make that plan a regular part of your life.

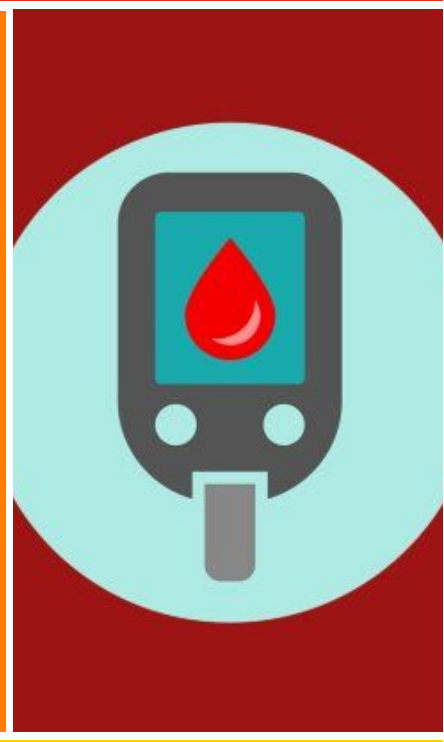

Eligibility requirements include: *All study related care will o Diagnosis of Type II Diabetes be provided at no cost*

o Hemoglobin A1c level > 7\% Diabetic-friendly snacks and o On stable medication and therapy informative pamphlets will be provided! 


\section{Appendix H}

\section{Certificates or Documentation of any Additional Certifications}

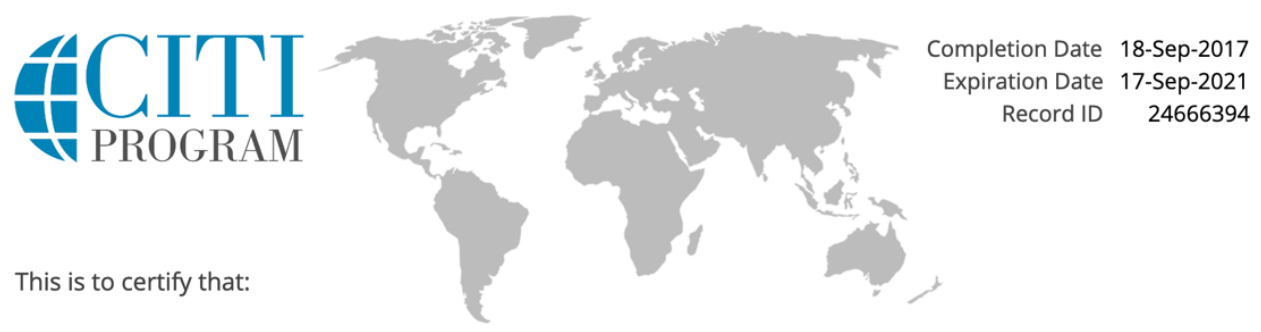

\section{Nishita Patolia}

Has completed the following CITI Program course:

Not valid for renewal of certification through CME. Do not use for (see Completion Report).

CITI Conflicts of Interest (Curriculum Group)

Conflicts of Interest (Course Learner Group)

1 - Stage 1

(Stage)

Under requirements set by:

University of San Diego

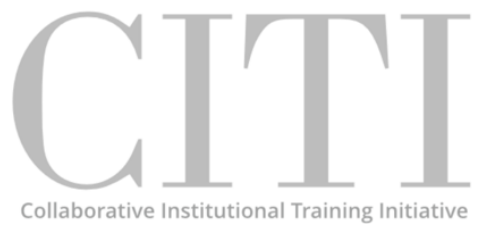

Verify at www.citiprogram.org/verify/?w10d1af66-94c4-4ded-ad1f-79efa8901135-24666394

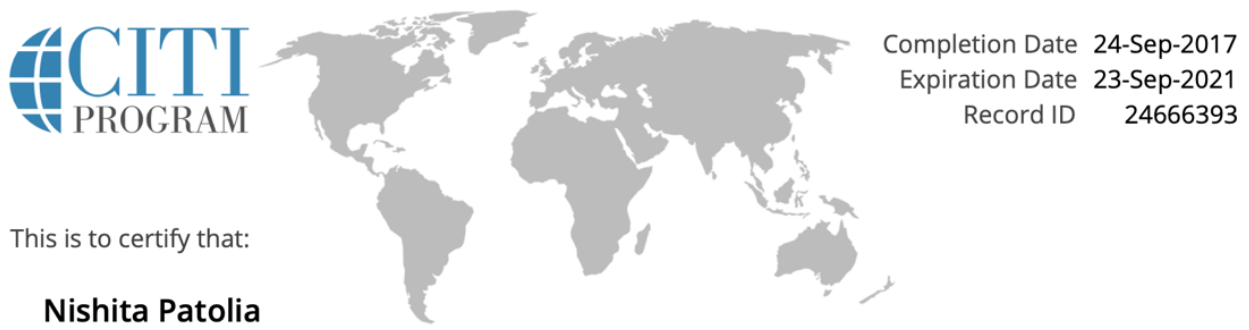

Has completed the following CITI Program course:

Responsible Conduct of Research

(Curriculum Group)

Social and Behavioral Responsible Conduct of Research Course (Course Learner Group)

1 - Basic Course

Under requirements set by:

University of San Diego

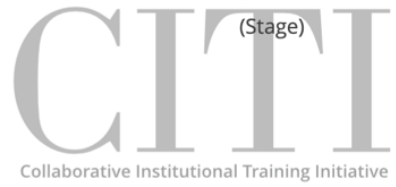

Verify at www.citiprogram.org/verify/?wc81 c12fc-f1da-4adc-820b-6d907acfd299-24666393 